\title{
Articles
}

\section{Understanding Origen: The Genre(s) of the Gospels in Light of Ancient Greek Philology and Modern Genre Theory}

\author{
CarlJohan Berglund \\ Uppsala University, Sweden \\ carl.johan.berglund@teol.uu.se
}

\begin{abstract}
The reflections of Origen of Alexandria ( $c a .185^{-254} \mathrm{CE}$ ) concerning the nature of the New Testament Gospels may be better understood if viewed in relation to a scheme of standard introductory questions used by ancient Greek philologists in their commentaries on classical Greek literature. While this scheme did not include questions about the form or genre of the writings to be analyzed, Origen repeatedly added such reflections when he adapted the scheme in his commentaries on biblical writings. These reflections inform us of his expectations of the Gospels. Using a modern concept of genre as a system of expectations shared between author and reader, and frequently intended to shape the worldview of the readers, Origen's views of the nature of the Gospels can be expressed as their simultaneous participation in two genres: Christian teaching and ancient historiography.
\end{abstract}

\section{Keywords}

Origen of Alexandria - exegetical methodology - Greek philology - genre - gospel ancient historiography 
While scholarly reflection on the exegetical methodology of Origen of Alexandria has largely revolved around his use of allegory and his alleged disregard of any historical meaning of the biblical writings, Bernhard Neuschäfer's revealing survey of Origen's use of the exegetical methodology of Greek philology has provided new possibilities for understanding his other exegetical techniques. ${ }^{1}$ One such possibility concerns the reflections he makes, both in the introductions to his commentaries on various biblical writings and intermittently in the course of the commentaries, on the nature or genre of the text he is analyzing. These reflections are shaped and informed by a scheme of standard introductory questions used by ancient Greek philologists in their introductions to commentaries on classical Greek literature, and examined by Neuschäfer, Ilsetraut Hadot, Ronald E. Heine and Jaap Mansfeld. ${ }^{2}$ While this scheme did not include questions about form and genre, Origen repeatedly adds reflections on the form of various biblical writings to his treatment of the standard questions about aim, utility, place in an order of lecture, reason for its title, authenticity, and disposition. In his voluminous commentaries on the Gospels of John and Matthew, Origen includes characterizations and descrip-

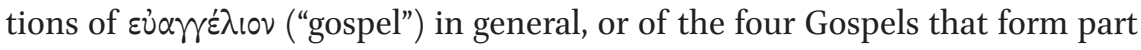
of the New Testament in particular. By examining these reflections, we may gain an understanding of Origen's views concerning the nature, or genre, of the Gospels. Ancient reflection on genre was, in general, too simple to express the practice of ancient authors, but Origen's view of the Gospels may be expressed using a modern concept of genre, in which a single text may participate in more than one genre at a time.

This article explores how the introductory questions of ancient Greek philology can be utilized to understand Origen's reflections on the nature of the Gospels, in order to express Origen's view of the nature of the Gospels in terms of a modern concept of genre.

1 B. Neuschäfer, Origenes als Philologe (Schweizerische Beiträge zur Altertumswissenschaft, 18), Basel, 1987 .

2 Neuschäfer, Origenes als Philologe, pp. 57-67; Simplicius: Commentaire sur les Catégories, ed. I. Hadot, (Philosophia antiqua, 50), Leiden, 1990, pp. 21-47; R. E. Heine, "The Introduction to Origen's Commentary on John Compared with the Introductions to the Ancient Philosophical Commentaries on Aristotle," in: Origeniana Sexta: Origène et La Bible, Leuven, 1995, pp. 5-12; J. Mansfeld, Prolegomena: Questions to Be Settled before the Study of an Author or a Text (Philosophia antiqua, 61), Leiden, 1994, pp. 10-57. 
Later-day reception of Origen's exegesis has largely revolved around various criticisms and matching defenses of his use of allegory, formulated from different angles according to the criteria of different eras, although there also has been some recognition of his knowledge and use of Greek philology.

The seventeenth-century scholar Richard Simon may be the first to claim that Origen's allegorical interpretations "completely destroy the truth of history." Jacques-François Denis is not alone in equating Origen's methodology with "allegorical exegesis." ${ }^{4}$ Eugène de Faye explains that Origen has developed his technique by studying, elaborating, and applying the methods of Alexandrian philologists, including textual criticism, grammatical analysis, and the use of other fields of knowledge to explain the text. ${ }^{5}$ He concludes, however, that these methods ultimately amount to substituting the meaning of the Scriptures with entirely foreign philosophical concepts. ${ }^{6}$ Intent on defending Origen against the double accusations of allegorical and non-Christian exegesis, Jean Daniélou makes a sharp distinction between "allegorical" and "typological" interpretations, and argues that Origen's typology respects the historical character of the biblical narrative and conforms to an earlier Christian interpretative tradition. ${ }^{7}$ Daniélou also notes that Origen, in his textual

"Origene établit avec tant de force en plusieurs endroits de ce Commentaire sur S. Jean le sens spirituel, qu'il détruit entierement la verité de l'histoire, si l'on n'aporte quelqu'adoucissement à ses expressions" (R. Simon, Histoire critique des principaux commentateurs du Nouveau Testament, depuis le commencement du Christianisme jusques à nôtre tems, Rotterdam, 1693, p. 47).

4 “L'exégèse allégorique, voilà l'unique procédé de découverte, réel ou apparent, que constitue la méthode d'Origène, si l'on peut donner le nom de méthode à ce jeu d'imagination, excellent moyen de paraître trouver ce qu'on déjà, mai non de découvrir ce qu'on n'a pas" (J. F. Denis, De la philosophie d'Origène, Paris, 1884, p. 33 apud K. J. Torjesen, Hermeneutical Procedure and Theological Method in Origen's Exegesis (PTS, 28), Berlin, 1986, p. 2).

5 E. de Faye, Origène: sa vie, son oeuvre, sa pensée, vol. 1 (Bibliothèque de l'École des hautes études. Section des sciences religieuses, 37), Paris, 1923, pp. 85-95.

6 "Lorsqu'on lit, soit les commentaires de notre auteur, soit ses homélies, il est naturel qu'on se demande comment il a pu altérer le sens des Écritures au point d'y substituer un sens philosophique entièrement étranger aux auteurs sacrés" (de Faye, Origène, pp. 94-95). Karen Jo Torjesen locates the genesis of this focus on the origin of Christian dogma to Adolf von Harnack's 1883 Handbuch der Dogmengeschichte (Torjesen, Hermeneutical Procedure, p. 3).

7 J. Daniélou, Origène (Génie du christianisme, 1), Paris, 1948, pp. 7, 137-138, 167-168; Torjesen, Hermeneutical Procedure, pp. 5-6. Daniélou, Origène, p. 175: "Nous espérons avoir montré dans le chapitre précédent que les lignes fondamentales de l'exégèse d'Origène se rattachent à la tradition catéchétique commune de l'Eglise. Mais ce n'est pas 
criticism of the Old Testament, adopts methods from Alexandrian philologists working with editions of Homer. ${ }^{8}$ In a similar way, Henri de Lubac defends Origen's Christian identity, devotion to Jesus, and concern for orthodoxy. ${ }^{9}$ De Lubac stresses that Origen's spiritual readings are in no way intended to undermine the historical sense of the text, ${ }^{10}$ and explains his perceived inability to recognize a simple metaphor as a misunderstanding: Origen's spiritual sense includes such ordinary figurative meanings. ${ }^{11}$ Marguerite Harl notes that Origen shows philological interest in the language employed by the evangelists and claims that his search for deeper meanings originate in his view that Jesus's healings took place simultaneously on a physical and a spiritual level. ${ }^{12}$

When R. P. C. Hanson sets out to analyze Origen's exegetical methodology, he has only allegory in mind. ${ }^{13}$ He traces the use of allegory through Second Temple Judaism and Hellenistic Greek culture, in the New Testament, in Justin Martyr ( $c a .100-165 \mathrm{CE})$ and in Clement of Alexandria ( $c a .150-215 \mathrm{CE})$, and argues that Origen has abandoned an original Palestinian Christian kind of allegory - which seems to be very similar to Daniélou's "typology" - for a non-Christian Alexandrian kind, heavily dependent on Philo. ${ }^{14}$ In Origen's use

la seule source à laquelle il a puisé. Dans son désir de mettre en œuvre tout ce qui pourrait l'aider à une meilleure intelligence de l'Ecriture, Origène s'est tourné également vers les autres traditions herméneutiques qui existaient à son époque. [...] Et c'est par là que se sont trouvés introduits dan son œuvre des éléments caducs, que relèvent de la culture de son temps et qu'on appelle son "allégorisme». Trop souvent on confond la typologie d'Origène avec cet allégorisme et à cause de cela on rejette en bloc son exégèse."

"L'obel et l'astérisque étaient les signes critiques employés par les grammairiens d'Alexandrie pour les éditions d'Homère. Ainsi le geste audacieux d'Origène a été d'appliquer au texte de l'Ecriture les méthodes critiques de son temps" (Daniélou, Origène, p. 141).

H. de Lubac, History and Spirit: The Understanding of Scripture according to Origen, tr. A. Englund Nash, San Francisco, 2007, pp. 6o-76. The French original appeared in 1950. This point has been repeated by many. Among those is H. Crouzel, Origène (Chrétiens aujourd'hui, 15), Paris, 1985, p. 94.

11 de Lubac, History and Spirit, pp. 9, 104-118, 128-132, 141, 317, 456; Torjesen, Hermeneutical Procedure, pp. 6-8; P. Martens, Origen and Scripture: The Contours of the Exegetical Life, Oxford, 2012, pp. 7-8. De Lubac, History and Spirit, p. 129: "His terminology is different from ours. Anytime he encounters an anthropomorphism, a metaphor, a parable, a figurative expression, he says that it must be taken in a spiritual sense."

M. Harl, Origène et la fonction révélatrice du verbe incarné (Patristica Sorbonensia, 2), Paris, 1958, pp. 146-57.

13 R. P. C. Hanson, Allegory and Event: A Study of the Sources and Significance of Origen's Interpretation of Scripture, London, 1959, pp. 7-8, passim.

Hanson, Allegory and Event, pp. 248-254, 368. Hanson assumes that he should be able to trace a connection from "the original historical context" of a biblical passage to its 
of allegory, Hanson states, he "breaks all rules and is unchartably subjective" in his determination to "deduce his own theology from the Bible."15 According to Hanson, Origen disregards the intentions of the human authors in order to use the same allegorical technique regardless of the genre of the text. ${ }^{16}$ This disregard is especially glaring when Origen, in Hanson's view, reduces history, which many biblical authors perceive to be God's primary field of self-revelation, to "no more than an acted parable, a charade for showing forth eternal truths about God."17

Jo Tigcheler shows a broader methodological interest. ${ }^{18}$ Although primarily concerned with technical vocabulary in the Commentary on Zechariah by Didymus the Blind ( $c a .313-398 \mathrm{CE}$ ), he also discusses Origen, and presents many of the findings in his study as equally valid for both. Tigcheler finds Didymus to be following a hermeneutical structure moving from more literal to less literal

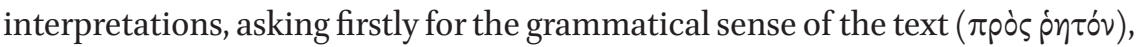
secondly to what the text refers ( $\kappa \alpha \theta^{\prime}$ i $\sigma \tau \tau$ opiav), thirdly how it can be understood in a figurative way ( $\left.x \alpha \tau^{\prime} \alpha \lambda \eta \eta \gamma o p i \alpha \nu\right)$, and fourthly how this would lead to a more profound meaning $\left(\kappa \alpha \tau^{\prime} \alpha \nu \alpha \gamma \omega \gamma \eta^{\prime} \nu\right) .{ }^{19}$

allegorical use presented by Origen, and he is seriously annoyed that neither Origen nor his own modern colleagues care to explain where this connection is to be found. This perceived deficiency suggests that Origen did not arrive at his spiritual interpretations by the route imagined by Hanson - and that further insight into Origen's methodological steps would be valuable (Hanson, Allegory and Event, pp. 7, 287-288).

Hanson, Allegory and Event, p. 245. It should be noted that his analysis occasionally shows some nuance, admitting that Origen often insists that the literal sense is true and valuable (Origen, Cels., 7.6o; Comm. Jo., 13.29, 28.23, Comm. Matt., 16.9), that he several times emphasizes the historical truth of an event (Comm. Matt., 10.17; Cels., 2.10, 2.33, 4.80; Hom. Gen., 2.2), and that he occasionally rejects allegorisations suggested by others (Comm. Matt., 15.15). See Hanson, Allegory and Event, pp. 235-239, 263.

Hanson, Allegory and Event, pp. 128, 208-209, 224-231, 246-247.

17 Hanson, Allegory and Event, p. 364.

18 J. Tigcheler, Didyme l'Aveugle et l'exégèse allégorique: étude sémantique de quelques termes exégétiques importants de son commentaire sur Zacharie (Græcitas christianorum primæva, 6), Nijmegen, 1977 .

19 Tigcheler, Didyme, pp. 52-53, 62-65, 75-81, 137-151. Both of Tigcheler's distinctions, the one between grammatical sense and the referent of the text, as well as the one between the allegorical and the anagogical meaning, in reference to both Origen and to Didymus, were previously made in W. A. Bienert, "Allegoria" und "Anagoge" bei Didymos dem Blinden von Alexandria (PTS, 13), Berlin, 1972, pp. 51-68, 108-9, 112-13. Bienert stresses the comprehensive education of Origen, as well as the continuity between Origen and Didymus the Blind: "Didymos der Blinde gehört zu den wenigen Theologen der alten Kirche, die das System des Origenes ohne Abstriche übernommen haben. Das zeigt sich nicht nur in 
Karen Jo Torjesen successfully discerns four steps in Origen's procedure: First, he quotes the verse (or verses) to be treated. Second, he explains the text within its own historical or rhetorical situation - in the case of Jeremiah, the historical situation of the prophet Jeremiah. Third, he "seeks to expose the in-

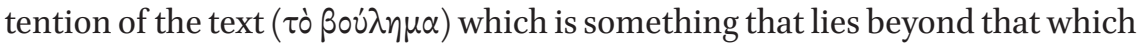
is stated." ${ }^{20}$ Fourth, he relates this intended meaning to the situation of the hearer, and makes it into something the hearer can receive and apply - some-

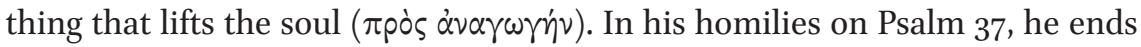
by repeating the interpreted verse, as spoken by the hearer himself. In his Commentary on the Song of Songs, the application to the individual hearer is preceded by an application to the Christian community. ${ }^{21}$ In his homilies on the same book, Origen follows the same procedure, but presents his results in a much simpler way. ${ }^{22}$ In the homilies on Numbers, Origen varies his pattern by starting not from the text but from a question relating to the narrated situation, indicating that the intended meaning ( $\left.\tau \dot{o} \beta \circ v^{\prime} \lambda \eta \mu \alpha\right)$ might reside in historical events rather than in the text as such. ${ }^{23}$ In the homilies on the Psalms and on Jeremiah, the application to the hearer proceeds immediately from the historical interpretation of the text, with no allegorical step in between. In con-

seiner exegetischen Terminologie..." Furthermore, he explicitly states that Didymus adopted the concept of $\alpha \nu \alpha \gamma \omega \gamma \eta$ from Origen (Bienert, "Allegoria" und "Anagoge," p. 163). "Den Begriff $\alpha \nu \alpha \gamma \omega \gamma \eta$ hat Didymos von Origenes übernommen und in ähnlicher Weise wie dieser in seiner Exegese verwendet" (Bienert, "Allegoria" und "Anagoge," p. 160). The distinction between grammatical sense and the referent of the text is commonly collapsed into "the literal sense" in studies of Origen's exegetical methodology. It is unfortunate that Torjesen, who notices this distinction in Tigcheler, and asserts that Origen makes the same distinction, occasionally also collapses it: "Origen always begins from the literal sense tò ṕtóv, which consists of the words of the text or the history and situation described in the text, and proceeds to a clarification and explanation of the literal sense" (Torjesen, Hermeneutical Procedure, p. 68, cf. 139). Torjesen criticizes Tigcheler for presenting "a purely hermeneutical structure" without a theological element that might delimit the exegete's range of allegorical interpretations. Within an unfortunate focus on allegory, this is valid criticism. See Ibid., pp. 10, 139 . Ibid., pp. 49-69, 148-174. The last fact is previously noted by Jacques Chênevert, who states: "Après avoir donné le sens littéral ou historique, il passe au sens spirituel, qu'il développe sous une double forme: celle de l'interprétation ecclésiologique et celle de l'interprétation morale, c'est-à-dire une interprétation centrée sur les relations entre l'Église et le Christ et, d'autre part, sur les relations individuelle avec le Verbe" (J. Chênevert, L'Église dans le Commentaire d'Origène sur le Cantique des cantiques (Studia. Travaux de recherche, 24), Brussels, 1969, p. 9). 
trast, when preaching on the Song of Songs Origen offers no non-allegorical interpretation, but moves immediately from the text to its interpretation in the context of a dialogue between Christ and the church. ${ }^{24}$ Torjesen concludes that Origen always aims to present a spiritual interpretation that is useful for the spiritual development of the reader or hearer, and adapts his exegesis to varying biblical genres. ${ }^{25}$

Although Hanson praises Origen for bringing "the whole weight of contemporary scholarship" to the exegetical task, he presents no content of this scholarship apart from allegory. ${ }^{26}$ Hanson remarks in passing that there might have been, prior to Origen's writing career, an established method of treating Scripture in the form of a written commentary, that Origen adopted from "the Gnostic Heracleon" (second century CE) and developed with astounding success. ${ }^{27}$ That this method consists of virtually all of the ancient Greek philological tradition, developed to interpret the Iliad and the Odyssey, has, by now, been thoroughly established.

The history and extent of Greek philology have been thoroughly explored by Rudolf Pfeiffer. ${ }^{28}$ Its relevance for understanding Origen's exegetical procedure has been successfully demonstrated by Bernhard Neuschäfer. ${ }^{29}$ That Heracleon preceded Origen as a competent Greek philologist has been meticulously shown by Ansgar Wucherpfennig. ${ }^{30}$ René Nünlist has expanded our insight into the wide array of concepts available to ancient Greek philologists by studying scholia - short, anonymous comments to specific passages in the classical literature, most commonly written in the margins of ancient manuscripts. ${ }^{31}$ Frances Young has located Origen's uptake of Greek philology within the framework of Greco-Roman education and learned culture $(\pi \alpha \iota \delta \varepsilon i \alpha)$, and

24 Torjesen, Hermeneutical Procedure, pp. 52, 58. In his Commentary to the Song of Songs, however, non-allegorical interpretations are present, albeit brief. See Chênevert, L'Église, p. 9; Crouzel, Origène, p. 92.

25 Torjesen, Hermeneutical Procedure, pp. 68-69; Martens, Origen and Scripture, pp. 9-10.

26 Hanson, Allegory and Event, p. 360.

27 Ibid., pp. 160-161. That Hanson views this "method" as consisting solely of the literary form of the commentary is clear when he states: "I do not agree with the suggestion frequently made by students of Origen's thought that he owed anything significant to Gnostic thought, with the possible exception that he derived the literary form of the commentary from Heracleon" (Hanson, Allegory and Event, p. 361).

28 R. Pfeiffer, History of Classical Scholarship. From the Beginnings to the End of the Hellenistic Age, Oxford, 1968.

29 Neuschäfer, Origenes als Philologe.

30 A. Wucherpfennig, Heracleon Philologus: Gnostische Johannesexegese im zweiten Jahrhun$\operatorname{dert}$ (wUNT, 142), Tübingen, 2002.

$31 \quad$ R. Nünlist, The Ancient Critic at Work: Terms and Concepts of Literary Criticism in Greek Scholia, Cambridge, 2009. 
argued that his application to the New Testament of the exegetical methodology he was trained to use in relation to the classical Greek literature constituted a cultural "takeover bid," in which he successfully attempted to let the Bible replace Homer and create an alternative Christian culture. ${ }^{32}$ Peter Martens has combined Torjesen's insights into Origen's exegetical aims with his use of Greek philology to produce a rather complete picture of Origen's ideal interpretation - and ideal interpreter - of the Bible. ${ }^{33}$ Lewis Ayres has expanded the discussion to several second-century Christian authors that, like Heracleon, preceded Origen in taking up Greek philology. ${ }^{34}$

In the present state of the discussion, it appears unnecessary to accuse Origen of non-conformance either to modern methodological standards or early Christian exegetical tradition. A more reasonable aim is to expand our understanding of how his interpretative practices adopted and adapted the exegetical methodology of Greek philology. This methodology, including its use of allegory, appears to be well established among Christian authors before his time, and to constitute a methodological standard to which he possibly could have aimed to conform.

\section{Introductory Questions in Ancient Greek Philology}

Ancient Greek philology was aimed to preserve, understand, and explain the Greek literary tradition. It developed mainly in Alexandria, in close proximity

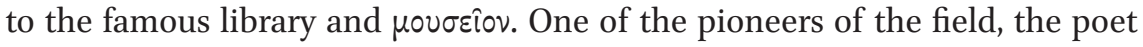
Callimachus of Cyrene ( $c a .310-240 \mathrm{BCE}$ ) is said to have catalogued the holdings of the Alexandrian library in 120 scrolls, categorizing them as oratory, history, laws, philosophy, medicine, lyric poetry, tragedy or miscellany. He is even said to have added brief commentaries to many of the entries, thereby stimulating subsequent scholars to produce commentaries of their own. ${ }^{35}$

Since ancient philologists were well aware that available manuscripts of

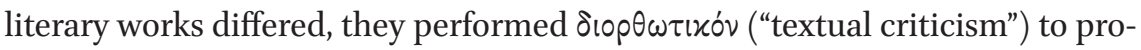

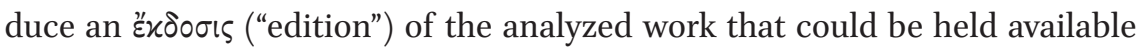

\footnotetext{
32 F. M. Young, Biblical Exegesis and the Formation of Christian Culture, Cambridge, 1997.

33 Martens, Origen and Scripture.

34 L. Ayres, "Irenaeus vs. the Valentinians: Toward a Rethinking of Patristic Exegetical Origins," JECs, 23/2 (2015), pp. 153-87.

35 J. A. McGuckin, "Origen as Literary Critic in the Alexandrian Tradition," in: Origeniana Octava: Origen and the Alexandrian Tradition, ed. L. Perrone (BETL, 164), Leuven, 2003, pp. 121-135, here 121-122.
} 
in the library for perusal and copying. ${ }^{36}$ They also engaged in $\xi^{\prime} \xi \eta \eta \gamma \eta \iota \varsigma$ ("expla-

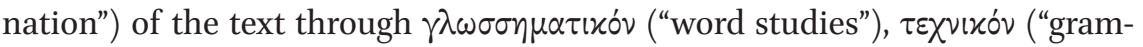
matical-rhetorical analysis"), $\mu \varepsilon \tau p i x o ́ v$ ("critique of style and meter") and

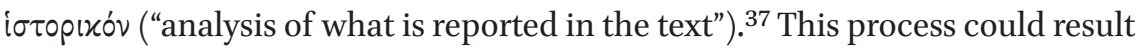
in a $i \pi 0 \mu \nu \eta \dot{\eta} \mu \alpha$ ("commentary") consisting of $\lambda \dot{\varepsilon} \mu \mu \alpha \tau \alpha$ ("running quotations") from the analyzed work, followed by comments and explanations. Such commentaries followed the analyzed work line by line or passage by passage, un-

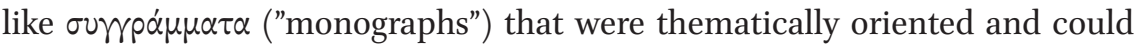
include analyses of more than one literary work. ${ }^{38}$ Origen studied Greek philology around $200 \mathrm{CE}$, and his commentaries adhere to the established form of his day. ${ }^{39}$

Philological commentaries frequently began, before the first $\lambda \varepsilon^{\prime} \mu \mu \alpha$, with a series of introductory questions about the text, most commonly concerning its (1) aim, (2) utility, (3) place in an order of lecture, (4) reason for its title, (5) authenticity, and (6) disposition. While this scheme was established as early as the third century $\mathrm{CE}$, the clearest descriptions of these six questions survive in the works of Ammonius Hermiae ( $c a .435^{-} 517 \mathrm{CE}$ ). In his commentary on the Categories by Aristotle (384-322 $\mathrm{BCE})$, Ammonius presents them as follows:

Our ninth point concerns how many and which inquiries it is necessary to perform in advance of the explanation of every book by Aristotle. We

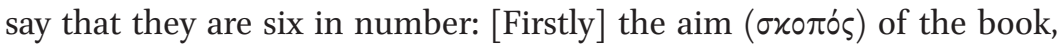
because just as the archer, for example, has a target towards which he shoots, and which he intends to hit, the writer also has an aim towards which he looks, and which he is eager to reach. It is therefore necessary to

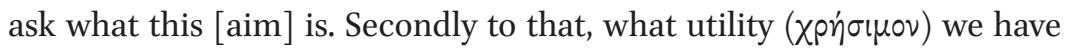
from the writing ( $\sigma \dot{v} \gamma \gamma \rho \alpha \mu \mu \alpha)$, if this has not been clarified together with

${ }_{3} 6$ The practical advantage of using a common set of terms in describing this methodology, such as these used here, is not intended to shadow the fact that ancient philologists sometimes used other terms, or (more frequently) made use of these or similar methods without naming them. Cf. Nünlist, The Ancient Critic at Work, pp. 3-4; Pfeiffer, History of Classical Scholarship, p. 216.

37 H.-I. Marrou, Histoire de l'éducation dans l'antiquité, Paris, 19605, pp. 229-242; Neuschäfer, Origenes als Philologe, pp. 139-140; Young, Biblical Exegesis, pp. 85-89; Martens, Origen and Scripture, pp. 41-42.

38 Pfeiffer, History of Classical Scholarship, pp. 3, 29, 105-112, 213-20.

39 Eusebius describes Origen's education in Hist. eccl., 6.2-3. Neuschäfer stresses that Origen did not encounter the Greek philological tradition in its Hellenistic stage, but it the form it took in higher education in the Roman Empire. Neuschäfer, Origenes als Philologe, pp. 35-38; McGuckin, "Origen as Literary Critic," p. 134. 
the aim, to which it usually corresponds. Thirdly, what is its place $(\tau \dot{\alpha} \xi \varsigma \varsigma)$ ? Fourthly, what is the reason ( $\left.\alpha i \tau^{\prime} \alpha\right)$ for the title ( $\left.\dot{\varepsilon}^{\prime} \pi \gamma p \alpha \varphi \eta^{\prime}\right)$, if this is not already clear as well, as in the cases of On the Heavens or On Generation

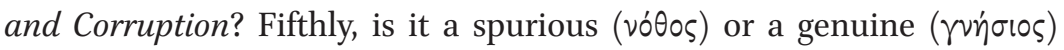
work of the philosopher? For many of the same have been put together and inscribed with the name of Aristotle, which one must refuse both because of form ( $(\varepsilon i \delta \circ \varsigma)$ and of matter ( $\tilde{v} \lambda \eta)$ - the form being the intricacy $\left(\pi \circ x_{i} \lambda i \alpha\right)$ of the thoughts and the truth that appears from the words, the

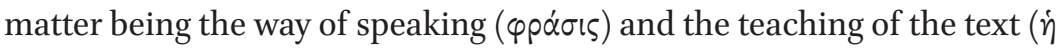

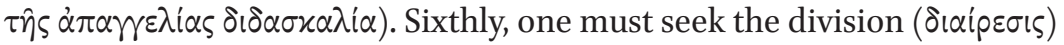
into main arguments $(\kappa \varepsilon \varphi \dot{\alpha} \lambda \alpha \iota \alpha)$. For just as the one who has carefully examined each of the human limbs and joints would know best how the whole human body is assembled from those parts, the one who has gone through in detail the main arguments into which a treatise ( $\lambda$ ó $0 \varsigma$ ) is divided also knows the treatise itself best. ${ }^{40}$

Although Ammonius here enumerates six standard questions, he does not strictly adhere to this scheme elsewhere. In another of his commentaries, Ammonius presents the same six questions in a different order, and adds a seventh concerning which part of philosophy the treatise belongs. ${ }^{41}$ The order used by other philologists varied significantly. All six questions were not always included, and the technical vocabulary varied. ${ }^{42}$ Introductory material could also

Ammonius, Commentary on Aristotle's Categories, in: CAG, vol. IV.4, 7.15-8.10 (ET: mine):

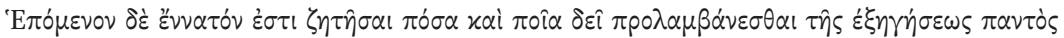

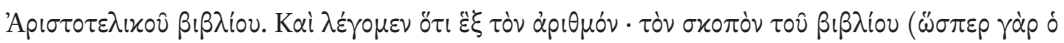

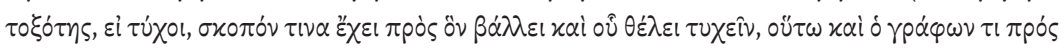

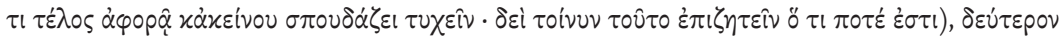

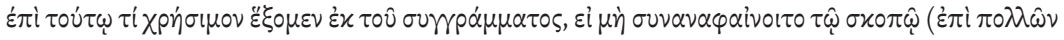

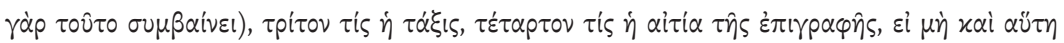

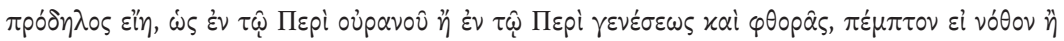

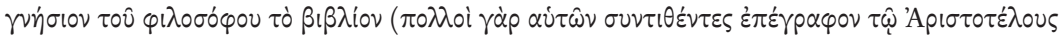

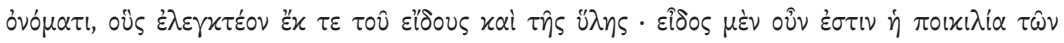

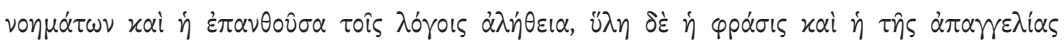

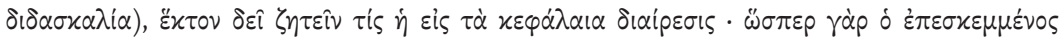

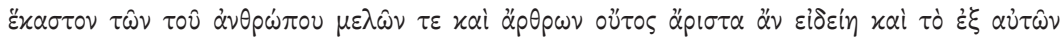

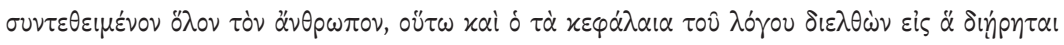

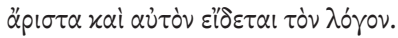

Ammonius, Commentary on Porphyry's Isagogē, in: $C A G$, vol. IV.3, 21.6-9. The order presented in this parallel is followed in Heine, "Introductions," p. 5 .

42 Neuschäfer, Origenes als Philologe, pp. 57-67; Hadot, Commentaire sur les Catégories, pp. 29-30; Mansfeld, Prolegomena, pp. 7-8, 10-11, 20-21, 173-74; Heine, "Introductions," p. 5 . 
appear in the course of the commentary, ${ }^{43}$ and multi-volume commentaries could revisit introductory questions when introducing subsequent volumes.

Ammonius's questions make use of distinctions and questions that had been established in Greek philology well before his time. Let us first notice the

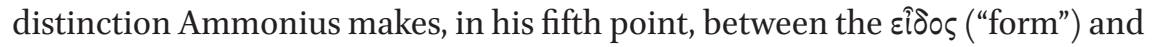
the $v \lambda \eta$ ("matter") of the text. The intricacy of thoughts and truths in the mind of the author seem to be more important to Ammonius than the actual phrasing and organization of the piece. Though clearly indebted to Platonic and Aristotelian ideas, this distinction is a variation of a standard distinction among ancient Greek philologists between what was said and how it was said. The subject matter or overall argument of the text (most often designated i $\pi \dot{\theta} \theta \varepsilon \sigma \iota \varsigma$ or res) was held apart from the way it was expressed (the $\lambda \varepsilon x \tau$ ixóv or verba). The most detailed elaboration on this distinction appears in On Demosthenes, by the Roman historian and teacher of rhetoric Dionysius of Halicarnassus ( $c a$. 6o-after 7 BCE).${ }^{44}$ His distinction is between on the one hand $\lambda \varepsilon \varkappa \tau$ เ

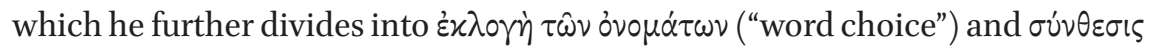

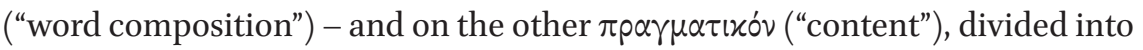

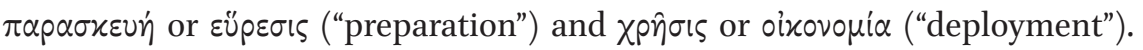
Dionysius's last term, oixovori $\alpha$, could also be used as a synonym for i $\pi$ ó $\theta \varepsilon \sigma \zeta{ }^{4}{ }^{45}$ Ammonius's $\varphi p \alpha \dot{\sigma} \iota \varsigma$ matches Dionysius's $\lambda \varepsilon \kappa \tau i x o ́ v$, his $\delta เ \delta \alpha \sigma \kappa \alpha \lambda i \alpha$ is synony-

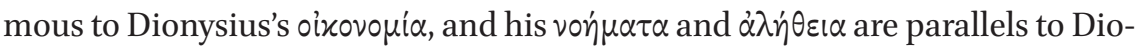

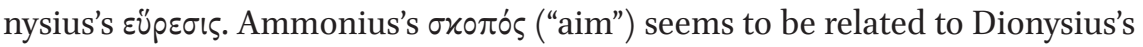
oixovopi $\alpha$, in that $\sigma x o \pi$ ós is the point the author is trying to make through his oixovopi $\alpha .{ }^{46}$ Similarly, the $x \varepsilon \varphi \dot{\alpha} \lambda \alpha \iota \alpha$ ("main points") of the work in Ammonius's sixth point can be seen as the constitutive elements of the oixovopi $\alpha$. Ammonius's $\chi p \eta$ ' $\sigma \mu o v$ is, on the other hand, defined as the use that the reader can

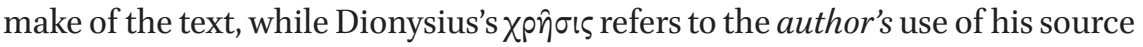
material. His third point, $\tau \dot{\alpha} \xi ı$, refers to the relation of this text to other works by the same author, and its place in a curriculum of works by this author. ${ }^{47}$

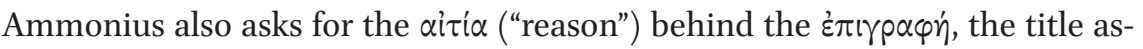
cribed to a literary work, not necessarily by its author, but as often by readers, librarians and booksellers.

C. Bammel, "Origen's Pauline Prefaces and the Chronology of his Pauline Commentaries," in: Origeniana sexta: Origène et la Bible (BETL, 118), Leuven, 1995, pp. 495-513, here 500.

44 Dionysius of Halicarnassus, Dem., 51. Cf. Thuc., 21.

45 Young, Biblical Exegesis, pp. 34-35, 81, 120; K. Eden, Hermeneutics and the Rhetorical Tradition: Chapters in the Ancient Legacy \& Its Humanist Reception (Yale Studies in Hermeneutics), New Haven, 1997, pp. 21, 27-30; Nünlist, The Ancient Critic at Work, pp. 23-25.

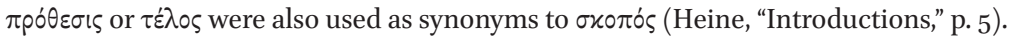
This point is clearer in the parallel in $C_{A G}$, vol. IV.3, 21.6-9 (Heine, "Introductions," p. 5). 
Bernhard Neuschäfer identifies several of Ammonius's questions in the Virgil commentaries by the roman philologists Aelius Donatus (fourth century $\mathrm{CE}$ ) and Servius (fl. ca. $400 \mathrm{CE}$ ), as well as in Origen's Commentary on the Song of Songs and Commentary on the Psalms. ${ }^{48}$ Ilsetraut Hadot traces all six of Ammonius's questions to several different commentators on the works of Aristotle, to the works of Porphyry of Tyre ( $c a .234-305$ CE), and to Origen's Commentary on the Song of Songs. ${ }^{49}$ Ronald E. Heine finds all six questions represented in various works by Alexander of Aphrodisias, a Peripatetic commentator on Aristotle who was active in the late second and early third centuries CE, although Ammonius's technical vocabulary is not used. ${ }^{50}$ Mansfeld discusses several other parallels, and concludes that Origen most likely learned the scheme of introductory questions from non-Christian commentaries that he had access to but now are lost. ${ }^{51}$ Heine concludes that these six questions were "discussed in philosophical schools as least as early as the beginning of the third century, and could have been part of Origen's education in the philosophical schools of Alexandria. They were certainly available to him prior to the time that he began to write commentaries." ${ }^{52}$

\section{$4 \quad$ Static and Dynamic Concepts of Genre}

In view of the complexity of introductory questions in the arsenal of ancient Greek philologists, it might appear surprising that the scheme did not include a question about genre. The main reason for this omission was that a commentator to Homer, Plato, or Aristotle needed only to identify the genre of epic poetry, dialogue, or philosophical treatise once, and had no need to repeat this discussion in commentaries to individual works. Origen, in contrast, had reason to discuss the various genres in the biblical literature, and repeatedly added such reflections to his introductions. ${ }^{53}$ A probable secondary reason was that ancient understandings of genre were somewhat limiting. The practice of ancient writers was much more sophisticated than what the classical theory of

48 Neuschäfer, Origenes als Philologe, pp. 58, 71, 84. Previously, Torjesen had noted that Origen introduces his homilies on Psalm 37 with two questions: "what is the Psalm about? and to whom is its interpretation addressed?" (Torjesen, Hermeneutical Procedure, p. 23).

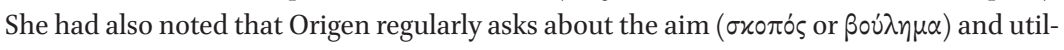
ity ( $\grave{\omega} \varphi \varepsilon \dot{\lambda} \varepsilon 1 \alpha)$ of any given text (Ibid., pp. 124-126).

$5^{0} \quad$ Heine, "Introductions," pp. 3-7.

$51 \quad$ Mansfeld, Prolegomena, pp. 55-57.

$5^{2}$ Heine, "Introductions," p. 7.

53 Hadot, Commentaire sur les Catégories, p. 37. 
genre could account for, and moderns scholars trying to understand ancient genres often abandon the use of ancient genre theory, opting rather to base their reflections on the practice of ancient authors. ${ }^{54} \mathrm{~A}$ similar move is needed for Origen: his reflections on the nature of the Gospels are not limited to the confines of ancient genre theory, but will prove to be a better match for a modern concept of genre as shared systems of expectations.

Ancient theories of genre are generally oriented around $\mu$ i $\mu \eta \sigma \varsigma \varsigma$ ("imitation"), and tend to view genres as static categories in which a certain form was used for a certain kind of content by a certain kind of author. Ambiguity in genre categorization was not recognized, not even when the Athenian dramatist Menander ( $c a .342-290$ BCE) and his contemporaries began to treat, in comedy form, themes that thitherto had been utilized solely in tragedy, thereby necessitating the term "New Comedy." 55 That ancient authors frequently "crossed" or "bended" genres is, by now, thoroughly established, ${ }^{56}$ but was never recognized in ancient genre theory. ${ }^{57}$ The Roman lyric poet Horace (65-8 вСE) even ridiculed the poet who would ignore the operis lex ("law of the genre”) that would forbid the poet from doing certain things, likening such a

54 J. Farrell, "Classical Genre in Theory and Practice," New Literary History, 34/3 (2003), pp. 383-408, here 383, 402-403; G. W. Most and G. B. Conte, "Genre," $O C D, 2012$.

Farrell, "Classical Genre," pp. 383-386, 389-39o. On this transition, see also Eric Csapo's argument that the two genres co-existed over a longer period: "The changes in comedy from the fifth to the fourth century are best understood, not as a succession of qualitatively distinct products, but as a shift in the dominance of one style over another" (E. Csapo, "From Aristophanes to Menander? Genre Transformations in Greek Comedy," in: Matrices of Genre: Authors, Canons, and Society, ed. M. Depew and D. Obbink (Center for Hellenic Studies colloquia 4), Cambridge, 2000, pp. 115-133, here 133). On the parallel case of Greco-Roman historiography, see John Marincola's argument "that the historiographical genres of the Greeks and the Romans were not static categories in which one writer merely followed all or most of the aspects of his predecessors, but rather that they were constantly dependent upon change and innovation ..." (J. Marincola, "Genre, Convention, and Innovation in Greco-Roman Historiography," in: The Limits of Historiography: Genre and Narrative in Ancient Historical Texts, ed. C. S. Kraus (Mnemosyne. Supplementum, 191), Leiden, 1999, pp. 281-324, here 320).

56 Wilhelm Kroll established that Roman authors crossed genres in Studien zum Verständnis der römischen Literatur, Stuttgart, 1924, pp. 202-224. Harold W. Attridge demonstrated creative use of ancient genres in his influential article "Genre Bending in the Fourth Gospel," Journal of Biblical Literature, 121/1 (2002), pp. 3-21.

57 Athenaeus Intellectuals at Dinner XI 505c has a quotation from Aristotle's On Poets (Rose's fragment 72) in which Aristotle remarks that certain works are simultaneously $\lambda$ ó yous and $\mu \mu \eta \dot{\sigma} \sigma \varsigma \varsigma$, which might suggest that he was prepared to put a text in one category based on

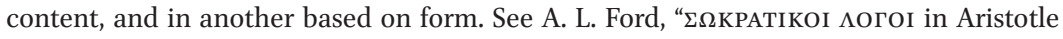
and Fourth-Century Theories of Genre," Classical Philology, 105/3 (2010), pp. 221-235, here 224-228. 
work to a painting of the upper parts of a beautiful woman combined with the lower parts of an ugly fish. ${ }^{58}$ As noted by Joseph Farrell, the irony that he expressed this rigidity in a letter combining didactic content with a poetic form might have escaped him entirely. ${ }^{59}$

Static taxonomies of genre have remained perplexingly popular into the modern era. In a most common understanding, a genre is a static category of literary texts with common features of style, form, and content. In this understanding, every text belongs to exactly one genre, and all the texts in the genre need to have all the necessary features in common. ${ }^{60}$ But such a static taxonomy fails to describe wide genres with diverging sub-genres and disallows any evolution or transmutation of old genres into new ones. ${ }^{61} \mathrm{Glenn}$ W. Most holds it to be "self-evident" that "no text belongs exclusively to a single genre" and proposes that genre should be understood as a system of expectations, shared and mutually calibrated between authors and readers within a cultural community. ${ }^{62}$ Others have proposed similar models where genres are systems

$5^{8}$ Horace, Ars, $1-5,135$.

59 The title used in medieval manuscripts for Horace's Ars poetica is Epistula ad Pisones (“Letter to the Brothers Piso") (Farrell, "Classical Genre," pp. 394-395).

6o For a selection of modern definitions of the genre concept within this understanding, see A. J. Köstenberger, "The Genre of the Fourth Gospel and Greco-Roman Literary Conventions," in: Christian Origins and Greco-Roman Culture: Social and Literary Contexts for the New Testament, ed. S. E. Porter and A.W. Pitts (Texts and editions for New Testament study, 9), Leiden, 2013, pp. 435-462, here 435 n. 1.

61 Additionally, Alastair Fowler has demonstrated that, in practice, the characteristics that are common to all members of any given genre are too few to meaningfully define the genre. Fowler proposes a genre theory based on "family resemblance," in which genres are networks of overlapping similarities that may apply unequally well to different texts in the genre. Texts that share more of the repertoire can be considered more typical representatives of the genre, while other texts may participate to a lesser extent in the genre without threatening to dissolve it altogether. See Marincola, "Greco-Roman Historiography," pp. 281-282; C. A. Newsom, "Spying Out the Land: A Report from Genology," in: Bakhtin and Genre Theory, Atlanta, 2007, pp. 19-30, here 22-23; C. A. Newsom, "Pairing Research Questions and Theories of Genre: A Case Study of the Hodayot," Dead Sea Discoveries, 17/3 (2010), pp. 270-288, here 270-273; R. Sheridan, "John's Gospel and Modern Genre Theory: The Farewell Discourse (John 13-17) as a Test Case," Irish Theological Quarterly, 75/3 (2010), pp. 287-299, here 293-296; R. Williamson, "Pesher : A Cognitive Model of the Genre," Dead Sea Discoveries, 17/3 (2010), pp. 307-331, here 341-344.

62 G. W. Most, "Generating Genres: The Idea of the Tragic," in: Matrices of Genre: Authors, Canons, and Society, ed. M. Depew and D. Obbink (Center for Hellenic Studies colloquia, 4), Cambridge, 2000, pp. 15-35, here 15-18; Most and Conte, "genre." "Generating Genres," pp. 17-18: "Genre is often formulated as a set of rules, but it may be better to understand it as a historically contingent and flexible reciprocal system of mutually calibrated 
of expectations that shape the reader's understanding of a text. In these models, a text that evokes expectations taken from multiple genres is said to "participate" in more than one genre. These expectations are variously fulfilled or subverted by the text, inevitably giving the reader new expectations and evolving his or her understanding of how the text participates in different genres. ${ }^{63}$ As a matter of course, this recognition of genres impacts the reader's interpretation of the material. ${ }^{64}$

One function of the expectations inherent in a genre is to shape the reader's understanding of real-world references in the text. Genres incorporate certain worldviews - modes of seeing and conceptualizing reality - which explains why we are less shocked by hearing about a murder in a crime thriller than in a news report. ${ }^{65}$ Robert Williamson applies this insight to pesher commentaries, ${ }^{66}$ to argue that their defining feature is that they see prophetic passages of the Hebrew Bible as mysteries that reveal secret information about events

expectations, correlating some participants who are more or less active (call them poets, through all poets are listeners or readers before, while and after they are poets) with others who are more or less passive (call them listeners or readers, though even today few human recipients seem to be as passive as our machines still are) within a loosely bounded but largely self-conscious cultural community (whose borders in space and time are often quite unclear), in which each group delegates to the other specific roles, duties, pleasures, and anxieties."

63 For Daniel Chandler and Michael Sinding, a genre definition starts in a prototype or a group of prototypes, in which compulsory and optional features for the genre may be identified. The genre is defined by these features, but also by certain relationships between them, and if all features are optional the relationships are the genre's essential ingredients. See R. A. Burridge, What Are the Gospels? A Comparison with Graeco-Roman Biography, Grand Rapids, 2004, pp. 35, 48-49, 53; Williamson, "Pesher," pp. 346-348, 352354; Sheridan, "John's Gospel and Modern Genre Theory," pp. 293-296.

64 S. Auken, "Genre and Interpretation," in: Genre and..., ed. S. Auken, P. Schantz Lauridsen, and A. Juhl Rasmussen (Copenhagen Studies in Genre, 2), Valby, 2015, pp. 154-183.

65 P. Merenlahti and R. Hakola, "Reconceiving Narrative Criticism," in: Characterization in the Gospels. Reconceiving Narrative Criticism, ed. D. M. Rhoads and K. Syreeni (JSNTSup, 184), Sheffield, 1999, pp. 13-48, here 38-40; Newsom, "Spying Out the Land," p. 29; Newsom, "Pairing Research Questions and Theories of Genre," p. 275; Williamson, “Pesher," p. 354.

66 There are fifteen such commentaries in the Qumran literature: Commentaries on Isaiah (4Q161-5, 3Q4), Hosea (4Q166-7), Micah (1Q14, 4Q168), Nahum (4Q169), Habakkuk (1QpHab), Zephaniah (1Q15, 1Q170), Malachi (4Q253a), and on the Psalms (1Q16, 4Q171, $4 \mathrm{Q}_{173)}$. For the fascinating question of how these relate to Greco-Roman commentaries, see M. Bockmuehl, "The Dead Sea Scrolls and the Origins of Biblical Commentary," in: Text, Thought, and Practice in Qumran and Early Christianity, ed. R. Clements and D. R. Schwartz (Studies on the Texts of the Desert of Judah, 84), Leiden, 2009, pp. 3-29; R. G. Kratz, "The pesharim of Qumran and Hellenistic Scholarship," in: The Bible and Hel- 
that are contemporary to the interpreter. Interpretative material that does not share this outlook on the text should not, properly speaking, be called pesher, even if they do use the word pesher ("interpretation") to mark the boundary between text and interpretation - which is the defining feature that has named this category of commentaries. ${ }^{67}$ Similarly, Richard A. Burridge claims that several ancient biographies are aimed to proclaim a peculiar worldview that the protagonist of the biography shares with its authors. ${ }^{68}$ Carolyn Miller argues that the most important feature for identifying the genre(s) of a text is neither its form nor its content, but what it is intended to accomplish in the social world of its readers. Miller's definition of genres as "typified rhetorical actions based in recurrent situations" has enabled a radical expansion of genre studies from literary texts to the de-facto genres of everyday social interaction. ${ }^{69}$

Using this modern understanding of genre as systems of shared expectations that are intended to shape the worldview of readers, Origen's view of the nature of the Gospels may be expressed in the terms of genre. The expectations on the Gospels he expresses in his reflections may be synthesized into the definition of one or more genres, in which he perceived the Gospels to participate.

lenism: Greek Influence on Jewish and Early Christian Literature, ed. T. L. Thompson and P. Wajdenbaum, London, 2014, pp. 212-229.

67 Williamson, "Pesher," pp. 356-36o.

68 Burridge, What Are the Gospels?, pp. 76-77.

69 C. R. Miller, "Genre as Social Action," Quarterly Journal of Speech, 70/2 (1984), pp. 151-167, here 151-152, 157, 159, 163-165; S. Auken, "Contemporary Genre Studies: An Interdisciplinary Conversation with Johannine Scholarship," in: The Gospel of John as Genre Mosaic, ed. K. Bro Larsen (Studia Aarhusiana Neotestametica, 3), Göttingen, 2015, pp. 47-66. Although Miller's article has proven especially influential, she has not been alone in requesting a broadening of the subject of genre. An important precursor is Mikhail Bakhtin, who already in the 1950s wrote an article on the difficulties of applying a genre theory developed for literary texts to spoken utterances, which was first published in 1979. See D. Duff, "The Problem of Speech Genres," in: Modern Genre Theory (Longman critical readers), London, 2000, pp. 82-97. Another is Jacques Derrida, who in 1980 reflected on the indifference of genres towards strict rules and laws: J. Derrida, "The Law of Genre," trans. A. Ronell, Critical Inquiry, 7/1 (1980), pp. 55-81. More recently, Michael Sinding has attempted to combine sociocognitive, rhetorical and literary perspectives on genre into a more complex model, in which the communicative purpose in a certain social context plays a part alongside medium, story-world and narration (M. Sinding, "A Sermon in the Midst of a Smutty Tale': Blending in Genres of Speech, Writing, and Literature," in: Cognitive Literary Studies: Current Themes and New Directions, ed. I. Jaén and J. J. Simon, Austin, 2013, pp. 145-161, here 146-148). 


\section{Origen on Genre in the Song of Songs}

In order to see how Origen applied the philological scheme of introductory questions to discuss genre, we may look at the introduction to his Commentary on the Song of Songs. ${ }^{70}$ Since this commentary is not available in the original Greek, but only in the Latin translation by Rufinus of Aquileia ( $c a$. 340-410), ${ }^{71}$ it does not allow conclusions regarding Origen's vocabulary, but suffices for a more general analysis of his chain of reasoning. ${ }^{72}$ In this introduction, which in Luc Brésard's and Henri Crouzel's edition is divided into four chapters, Origen shows a great interest in the form of the work - possibly to provide additional motivation for his choice to treat it solely as an allegory, and to refrain from considering any literal level of the text. In Rufinus's translation, the first word of the introduction even reads like a genre identification:

It seems to me that this little book is an epithalamium (Epithalamium libellus hic), that is to say, a marriage-song (nuptiale carmen), which Solomon wrote in the form of a drama (dramatis) and sang under the figure of the Bride, about to wed and burning with heavenly love towards her Bridegroom, who is the Word of God. And deeply indeed did she love Him, whether we take her as the soul made in His image, or as the Church. ${ }^{73}$

70 As originally done independently by Neuschäfer and Hadot: Neuschäfer, Origenes als Philologe, pp. 77-84; Hadot, Commentaire sur les Catégories, pp. 36-42. Parts of Hadot's study had been previously published as I. Hadot, "Les introductions aux commentaires exégétiques chez les auteurs néoplatoniciens et les authers chrétiens," in: Les règles de l'interprétation, ed. M. Tardieu, Paris, 1987, pp. 99-122.

71 Origen wrote ten books on the Song, of which four survive in Rufinus's translation. See L. Brésard and H. Crouzel, "Introduction," in: Commentaire sur le cantique des cantiques (sc, 375), Paris, 1991, pp. 9-77, here 13-14. English translations are taken from Origen, The Song of Songs: Commentary and Homilies, trans. R. P. Lawson (Ancient Christian Writers, 26), New York, 1957.

72 Torjesen reviews scholarly opinion on Rufinus's and Jerome's translations of Origen's works and concludes: "In summary, the consensus of opinion is that the methods of translation used by Jerome and Rufinus are such that their work cannot be used for critical reconstruction of the text. On the other hand, most scholars agree that their translations faithfully reproduce Origen's thought" (Torjesen, Hermeneutical Procedure, pp. 14-18; Brésard and Crouzel, "Introduction," pp. 13-16).

73 Origen, Comm. Cant., pr.1.1 (sc, 375, 80; Eт: Lawson): Epithalamium libellus hic, id est nuptiale carmen, dramatis in modum mihi videtur a Solomone conscriptus, quem cecinit instar nubentis sponsae et erga sponsum suum, qui est Sermo Dei, caelesti amore flagrantis. Adamavit enim eum sive anima quae ad imaginem eius facta est, sive ecclesia. 
In terms used by Greek philologists, what Origen is doing here is to present the

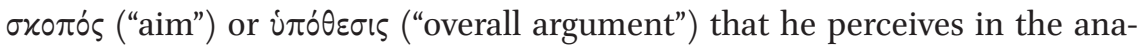
lyzed text: to express the love towards Christ (God's Logos) experienced either by an individual soul or by the personified Christian community as a whole. ${ }^{74}$ In this context, he also treats the form used by the author, and notes that it is dramatized and structured around the comings and goings of different characters - the Bride, the Bridegroom, and their respective friends. ${ }^{75}$ Whether the original Greek contained characterizations equivalent to the Latin epithalamium or nuptiale carmen is not certain. At the very least, Origen's reflections on the form of the Song of Songs have led Rufinus to present these genre identifications. Next, Origen remarks that the Song of Songs is not intended for anyone "that lives only after the flesh," but "should be reserved for study till the last." This section clearly responds to a version of the question about $\tau \dot{\alpha} \xi$ is ("place"), namely the place of the text in a curriculum of recommended readings for students. ${ }^{76}$

At the end of the first chapter, Origen presents his plan for the remainder of the introduction:

Before we come to consider the things that are written in this book, therefore, it seems to me necessary to say a few things about love (amor) itself, which is the main theme (causa praecipua) of this Scripture; then about the order of the books (ordo librorum) of Solomon, among which we find that this one is put third; then about the name (attitulatio) of the book itself, why it is entitled The Song of Songs; and, lastly, for what apparent

74 In the course of the Commentary, Origen regularly presents first an interpretation in the context of the church, then a second interpretation in the context of the progress of the soul (Torjesen, Hermeneutical Procedure, pp. 54-57). The contrast between the Gentile Bride and her Jewish friends, which leads Elizabeth A. Clark to pronounce the relation between Jews and Gentiles to be an important (secondary) theme perceived by Origen in the Song of Songs, is not visible until later in the Commentary (E. A. Clark, "Origen, the Jews, and the Song of Songs: Allegory and Polemic in Christian Antiquity," in: Perspectives on the Song of Songs, ed. A. C. Hagedorn, Berlin, 2005, pp. 274-293, here 274, 282-284).

75 Questions of who are speaking in a dialogue, and how they should be interpreted allegorically, were common in commentaries to both Homer and Plato. Hadot, Commentaire sur les Catégories, pp. 33-37; Mansfeld, Prolegomena, pp. 12-13.

${ }_{76}$ So also Neuschäfer and Hadot. Neuschäfer remarks that the reader would expect, in this context, information on the difficulty level of the text (Neuschäfer, Origenes als Philologe, p. 79). Demands that the reader should have achieved a certain moral purity before tackling certain books are also made in introductions to commentaries on Aristotle (Hadot, Commentaire sur les Catégories, p. 38). 
reason it is written in dramatic form (dramatis in modum), and like a story that is acted on the stage, with dialogue between the characters. ${ }^{77}$

Origen explicitly undertakes to answer the first, third, and fourth of Ammonius's questions - those about aim ( $\sigma x o \pi o ́ \varsigma)$, place ( $\tau \dot{\alpha} \xi ı \varsigma)$ and reason for the title

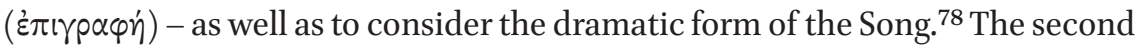
chapter of his introduction amounts to a $\gamma \lambda \omega \sigma \sigma \eta \mu \alpha \tau$ เóv ("word study") on the concept of love, which Origen views as the main theme of the Song of Songs. The third responds to another version of the question about $\tau \dot{\alpha} \xi ı$ ("place"), namely the place of the analyzed text among the works of its author. The two treatments of the question are closely related, since Origen here presents the three books associated with Solomon - Proverbs, Ecclesiastes, Song of Songs - as corresponding to three stages through which the human soul advances in the Christian philosophy. The Song of Songs corresponds to the most advanced stage, and should therefore be saved for last. By emphasizing that the Song of Songs is an advanced and esoteric book, he strengthens his case that it is written as an allegory and needs a skilled interpreter to be fully appreciated. ${ }^{79}$ The fourth chapter of the introduction concerns the question of $\dot{\eta} \alpha i \tau i \alpha$ in

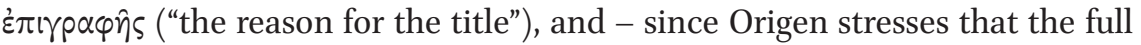
title, as given in Song 1:1, includes the identification of Solomon as its author ${ }^{80}$

77 Origen, Comm. Cant., pr. 1.8 (sc, 375, 87; ET: Lawson): Igitur necessarium mihi videtur, antequam ad ea quae in hoc libello scripta sunt discutienda veniamus, de amore prius ipso, qui est scripturae huius causa praecipua, pauca disserere, et post haec de ordine librorum Solomonis, in quibus hic liber tertio loco positus videtur; tum etiam de attitulatione libelli ipsius, cur Canticum Canticorum superscriptus sit, post etiam quomodo dramatis in modum, et tamquam fabula quae in scaenis personarum immutatione agi solet, videatur esse compositus.

78 Neuschäfer, Origenes als Philologe, pp. 79-80; Hadot, Commentaire sur les Catégories, p. 38. Without knowledge of Ammonius's scheme, Marguerite Harl finds four similar questions: "de quelle sorte d'amour est-il question dans ce cantique? Pourquoi ce livre est-il le troisième des ouvrages de Salomon? Que signifie le redoublement du titre, «Cantique des cantiques»? Comment, enfin, interpréter le genre «dramatique»" (M. Harl, "Les trois livres de Salomon et les trois parties de la philosophie dans les prologues des commentaires sur le Cantique des Cantiques (d'Origène aux chaînes exégétiques grecques)," in: Texte und Textkritik: eine Aufsatzsammlung, Berlin, 1987, pp. 249-269, here 251).

79 Torjesen, Hermeneutical Procedure, pp. 72-73; Neuschäfer, Origenes als Philologe, pp. 80-82; Harl, "Les trois livres de Salomon," pp. 250-255, 269; Hadot, Commentaire sur les Catégories, pp. 40-42; Mansfeld, Prolegomena, p. 13.

$80 \quad$ Origen, Comm. Cant., pr. 4.15-16, 29-31. 
- also the question of authenticity. ${ }^{81}$ After the first $\lambda \dot{\varepsilon} \mu \mu \alpha$, Origen returns to the form of the work and to the reason why this form was chosen. ${ }^{82}$ Ammonius's

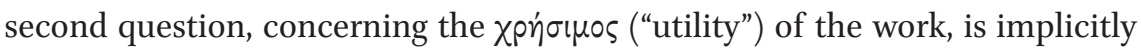
answered in the identification of the main theme, to which Ammonius holds

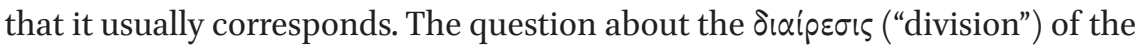
work seems to have been answered within the treatment of its dramatic form, since the divisions that Origen perceives within the Song are created by changes of speakers. ${ }^{83}$

From this analysis we may conclude that even if Origen does not mention all of Ammonius's questions, in one form or another he considers all of them. ${ }^{84}$ In his adaptation of the philologists' scheme of introductory questions, he gives ample space to the treatment of the form of the writing, presenting it as a dramatized poem reflecting on the idealized human love towards the divine Logos.

$81 \quad$ Pace Mansfeld, who states: "For Origen, the question of authenticity is clearly irrelevant in regard to this work" at Mansfeld, Prolegomena, p. 11. The issue is not irrelevant for Origen, just undisputed. As noted by Mansfeld, it is more relevant in his commentaries on the Psalms, where he deals with the ascriptions of individual psalms to individual purported authors (Ibid., pp. 14-15).

82 It is somewhat surprising that this reflection is not presented before the first $\lambda \varepsilon \dot{\varepsilon} \mu \alpha$, since Origen explicitly states that he is going to treat this subject "before we come to consider the things that are written in this book." Possibly, a longer section on the subject, at the end of the introduction, has been left out by Rufinus or a later copyist. Brésard and Crouzel find no trace of the treatment, and suggest that Origen forgot it or Rufinus left it out. Harl finds it after the first $\lambda \dot{\varepsilon} \mu \mu \alpha$. Hadot suggests that Rufinus might have moved it there from the introduction. Without referring to this particular case, Bammel remarks that introductory material may regularly spill over from the preface to the beginning of the commentary. See Brésard and Crouzel, "Introduction," pp. 19-20; Harl, "Les trois livres de Salomon," p. 251; Hadot, Commentaire sur les Catégories, pp. 38-39; Bammel, "Origen's Pauline Prefaces and the Chronology of his Pauline Commentaries," p. 500.

83 Such division is noted by Torjesen, Hermeneutical Procedure, p. 55. The analysis of philosophical content in dramatic form may be compared to the more specialized introductory questions used for the Platonic dialogues, as done by Hadot, Commentaire sur les Catégories, pp. 33-37.

84 Caroline Bammel makes similar analyses of the introductions to Origen's commentaries to the Pauline epistles, none of which is available in the original Greek, finding several possible points of contact with Ammonius's scheme (Bammel, "Origen's Pauline Prefaces and the Chronology of his Pauline Commentaries," pp. 498-511). 
The introduction to Origen's Commentary on the Gospel of Matthew is not extant in a form that allows us to draw conclusions on Origen's views on the nature of the Gospel of Matthew. ${ }^{85}$ The commentary does, however, contain a short discussion of the different oral genres used by the Matthean Jesus in his preaching, which illuminates Origen's use of the concept of genre.

After the $\lambda \varepsilon \dot{\varepsilon} \mu \alpha \alpha$ quoting the parable of the hidden treasure in Matt 13:44, Origen offers a reflection on how Jesus's habit of speaking in parables works differently when he is speaking to his disciples rather than to the crowds. Origen makes a distinction between a ó $\mu \delta_{i} \omega \sigma \iota \varsigma$ ("simile") and a $\pi \alpha \rho \alpha \beta 0 \lambda \eta$ ' ("parable"), both of which he views as sub-categories of a more general genre, which is also called "simile:"

From this it is clear that there is a difference between a simile ( $\left.\dot{\mu} \mu 0^{\prime} \omega \sigma \iota \varsigma\right)$ and a parable $(\pi \alpha \rho \alpha \beta \circ \lambda \eta \dot{)}$. The simile seems to be generic ( $\gamma \varepsilon v i x o ́ s)$ and

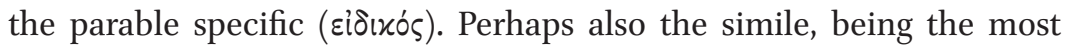
generic (category) for the parable, includes as specific categories both the parable and - named identically to the generic - the simile. ${ }^{86}$

Apparently, Origen has noted that in Matt 13:10-17, Jesus states that he speaks in parables $(\pi \alpha \rho \alpha \beta o \lambda \alpha i)$ in order to have his preaching understandable for his disciples, but indecipherable for the general public. He has also noted that the similes in Matt 13:1-43 are explicitly labeled $\pi \alpha p \alpha \beta 0 \lambda \eta \dot{\eta}$, while the one in 13:44 is not, and is trying to use this fact to discern between two genres of similes, based on whether they are meant to be understood by their hearers. ${ }^{87}$ Origen's

85 Origen, Comm. Matt. is extant in two non-interdependent manuscripts from the thirteenth and fourteenth centuries. Together, they cover books 10-17, commenting on Matt 13:36-22:33. Comments on Matt 22:34-27:66 are extant in Latin translation (R. Girod, "Introduction," in: Commentaire sur l'Évangile selon Matthieu (sC, 162), Paris, 1970, pp. 7-138, here 124-126). There is also a short quotation in Eusebius, Hist. eccl. 4.25.4-6 that may be taken from the introduction. The quoted text enumerates the four Gospels, their putative authors, and in two cases their intended audiences. If genuine, it would fit well within a reflection on the $\tau \dot{\alpha} \xi ı \varsigma$ ("place") of the Gospel of Matthew among the Christian Scriptures.

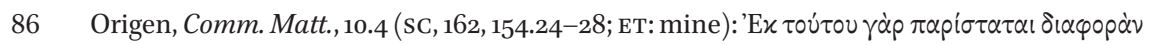

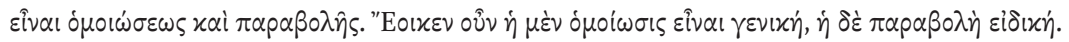

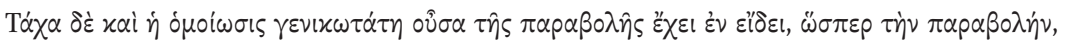

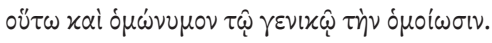

87 Young, Biblical Exegesis, pp. 85-86. 


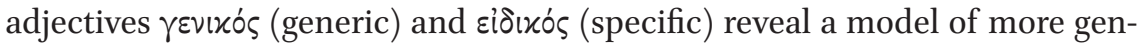

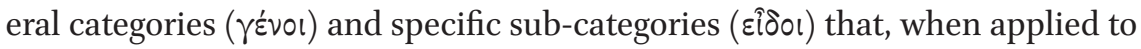
written texts, are similar to modern genres and sub-genres. That Origen's terminology is not limited to literary genres is clear from the next sentence, where Origen refers to similarly structured classes of mental impulses (óprí) to argue that it is not unreasonable to have a general category that shares its name with one of its own sub-categories.

When Origen in Matt 13:53 finds the word $\pi \alpha \rho \alpha \beta \circ \lambda \eta \dot{~ u s e d ~ t o ~ r e f e r ~ b a c k ~ t o ~ a l l ~}$ the similes in Matthew $13,{ }^{88}$ he reconsiders his position. After admitting that his distinction between parables and similitudes appears to be in some tension with Matt 13:53, he presents four ways to solve the problem:

We therefore wonder whether all this has to be rejected, or if we must speak of two kinds of parables $(\pi \alpha p \alpha \beta 0 \lambda \eta \dot{\eta})$ - those spoken to the crowd and those proclaimed to the disciples - or else if we should think of the word parable as homonymous (ó $\left.\omega^{\prime} v \nu \mu \circ \varsigma\right)$, or whether "When Jesus finished these parables" must refer only to the parables above, before the

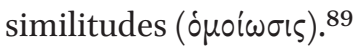

Origen is apparently struggling here, and seems not to know whether to revert his distinction altogether, to reposition the distinction to refer either to two kinds of $\pi \alpha \rho \alpha \beta 0 \lambda \dot{\eta}$ or two separate categories honomymously named $\pi \alpha \rho \alpha \beta 0 \lambda \dot{\eta}$, or to claim that this reference to parables only refers to the similes in Matt 13:1-43, which are explicitly called parables, and not to those in Matt 13:44-52, which are not. These alternatives are not clearly distinct, and he never manages to choose between them, leaving the issue rather awkwardly unsolved.

What can be concluded from these passages is that a concept of genre was available to Origen as one of his analytical tools, even though his use of it was not always well thought out and defendable.

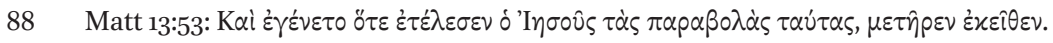

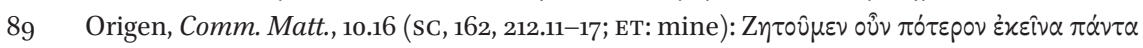

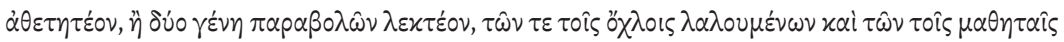

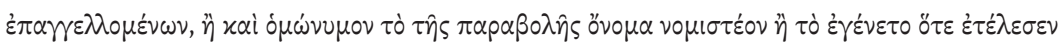

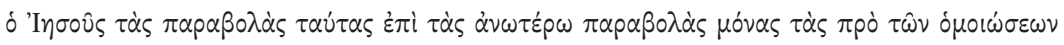

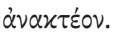


The introduction to Origen's Commentary on the Gospel of John is dominated by Ammonius's third and fourth questions - those about place $(\tau \dot{\alpha} \xi ı)$ and title

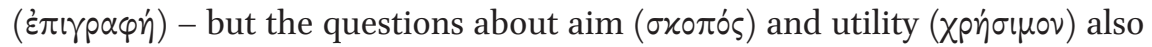
receive ample treatment within this context. ${ }^{90}$ Origen starts his introduction with the question of the ideal interpreter of the teachings of Christ, but soon starts to seamlessly interleave this topic with the question of the place of the Fourth Gospel within the Christian Scriptures. ${ }^{91}$ When Origen proceeds to discuss the reason for the title, he explicitly states his intention to do so, giving us

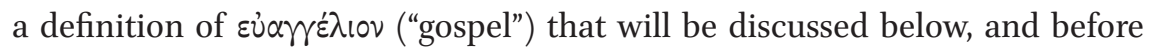
the first $\lambda \varepsilon^{\prime} \mu \mu \alpha$ he explicitly explains his discussion of preliminaries to have reached their end. ${ }^{92}$

Within these reflections, Origen makes subtle distinctions between the Gos-

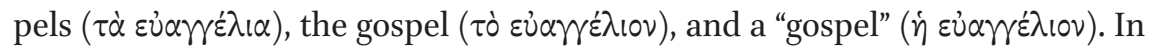
plural, with the definite article $\tau \dot{\alpha}$, "the Gospels" almost always refer to the four Gospels in the New Testament. ${ }^{93}$ When used with the singular neutral article $\tau \dot{0}$, "the gospel" may refer to one of these Gospels, but more frequently Origen uses this form to refer to the central Christian message of Christ's resurrection and humans' salvation - the central content rather than the specific narrative

90 Origen, Comm. Jo. is extant in one thirteenth-century manuscript and eight later, dependent manuscripts. Of the thirty-two books Origen originally wrote, covering John 1:1-13:32, nine survive. See E. Preuschen, "Einleitung," in: Werke. Bd 4, Der Johanneskommentar (Die griechische christliche Schriftsteller der ersten [drei] Jahrhunderte, 10), Berlin, 1903, pp. IX-CVIII, here IX-XL; C. Blanc, "Avant-propos," in: Commentaire sur Saint Jean. Texte grec, avant-propos, traduction et notes par Cécile Blanc (sc, 120), Paris, 1966, pp. 7-42, here 41; R. E. Heine, "Introduction," in: Commentary on the Gospel according to John: Books 1-10, trans. R. E. Heine (Fathers of the Church, 80), Washington, D.C., 1989, pp. 3-28, here 7-10.

91 Heine, "Introductions," pp. 8-11.

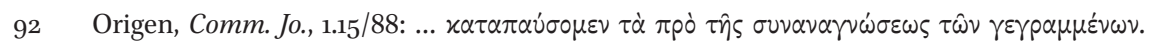
These explicit transitions are noted in Heine, "Introductions," p. 11.

93 According to Jerome's Latin translation of his homilies on Luke, Origen also used the plural to refer to non-canonical gospels such as the Gospel of the Egyptians and the Gospel of the Twelve Apostles. Origen Hom. Luc., 1.2 (sc, 87, 100.11-23): Ecclesia quatuor habet evangelia, haeresis plurima, e quibus quoddam scribitur secundum Aegyptios, aliud iuxta Duodecim Apostolos. Ausus fuit et Basillides scribere evangelium et suo illud nomine titulare. Multi conati sunt scribere, sed quatuor tantum evangelia sunt probata, e quibus super persona Domini et Salvatoris nostri proferenda sunt dogmata. Scio quoddam evangelium, quod appellatur secundum Thomam, et iuxta Mathiam, et alia plura legimus, ne quid ignorare videremur propter eos, qui se putant aliquid scire, si ista cognoverint. Sed in his omnibus nihil aliud probamus nisi quod ecclesia, id est quatuor tantum evangelia recipienda. 
of one of the Gospels. ${ }^{94}$ And sometimes, Origen uses the feminine article $\dot{\eta}$ to make it clear that he is referring to the word "gospel," or a general category, rather than to any specific good news.

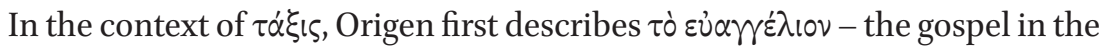
second sense above - as the $\alpha \pi \alpha p X \dot{\eta}$ ("first fruits") of the Scriptures. ${ }^{95}$ Since the central Christian message is also proclaimed by Paul and other New Testament writers, Origen proceeds to designate all of the New Testament as, in a sense, gospel, even though he remarks that the designation is more fitting for writings that directly relay the words and deeds of Jesus, and less so for writings that refer to him in a less direct way. ${ }^{96}$ The defining factor in making a piece of early Christian writing "gospel" is not the inclusion of biographical material concerning Jesus, but the educational intent to teach central dogma about him: 97

If we should ask, what is the task of the evangelist, [...] the distinguishing

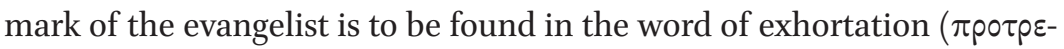
$\pi \tau i x o ́ s)$ through which he reaffirms the things reported concerning Jesus, so in every way (all) the writings of the apostles can be said to be gospel. ${ }^{98}$

This educational intent is here explicitly connected with the human authors of the early Christian writings. Elsewhere in Origen, it is also associated with the universal pedagogy of the divine Logos. ${ }^{99}$

94 The usage of $\varepsilon \dot{\jmath} \alpha \gamma \varepsilon \dot{\varepsilon} \lambda$ เov to refer to the central message of Christianity is well established in the first two centuries $\mathrm{CE}$, and at what point the word takes on the sense of a specific written narrative is disputed. See H. Koester, Ancient Christian Gospels: Their History and Development, London, 1990, pp. 1-16, 22-23, 27; A. Y. Reed, "ЕҮАГгеАIOn: Orality, Textuality, and the Christian Truth in Irenaeus' Adversus Haereses," vc, 56/1 (2002), pp. 11-46; A. Y. Collins, Mark: A Commentary (Hermeneia), Minneapolis, 2007, pp. 15-17; J. A. Kelhoffer, Conceptions of "Gospel" and Legitimacy in Early Christianity (wUNT, 324), Tübingen, 2014, pp. 40-41.

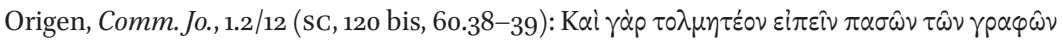

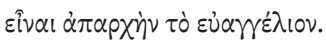

96 Origen, Comm. Jo., 1.2/12-3/20, 4/25-26. Cf. Heine, "Introductions," pp. 8-9; F. Watson, Gospel Writing: A Canonical Perspective, Grand Rapids, 2013, pp. 533-37.

97 Torjesen, Hermeneutical Procedure, pp. 128-29.

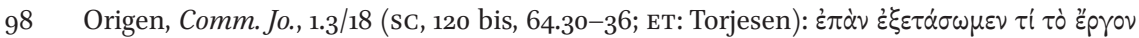

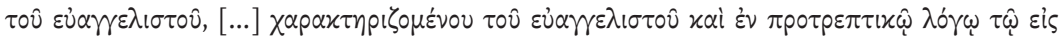

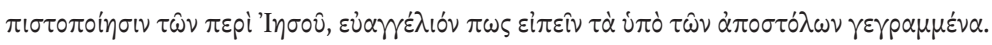

Torjesen, Hermeneutical Procedure, pp. 128-29. 
Secondly, he proclaims that there are four Gospels - in the first sense above - and that the Gospel of John is the $\dot{\alpha} \pi \alpha p x \dot{\eta}$ ("first fruits") of the Gospels. ${ }^{100}$ For this honorary position of the Fourth Gospel, he gives two motivations: Firstly, the Johannine Jesus is presented without a human genealogy; while Matthew

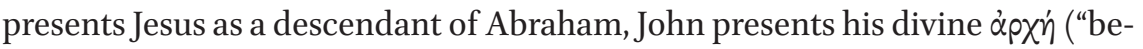

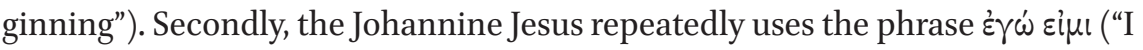
$\mathrm{am}^{\prime \prime}$ ) to apply the divine name to himself. Both these traits lead to the divinity of Jesus being more fully manifested in the Fourth Gospel:

[B] ut indeed he reserves for the one who leaned on Jesus' breast the greater and more perfect expressions ( $\lambda$ ó $0 \varsigma$ ) concerning Jesus, for none of those manifested his divinity $(\theta \varepsilon \dot{\tau} \tau \eta \tau \alpha)$ as fully as John when he presented him as saying, "I am the light of the world"; [...] "I am the alpha and omega, the beginning and the end, the first and the last." We might dare say, then, that the Gospels ( $\tau \dot{\alpha} \varepsilon \dot{\jmath} \alpha \gamma \varepsilon \dot{\varepsilon} \lambda 1 \alpha$ ) are the firstfruits ( $\dot{\alpha} \pi \alpha p \times \dot{\eta})$ of all Scriptures, but that the firstfruits of the Gospels is that according to

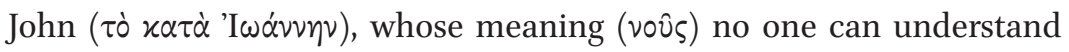
who has not leaned on Jesus' breast nor received Mary from Jesus to be his mother also. ${ }^{101}$

This passage is an illuminating example of how Origen interleaves multiple introductory questions into one chain of reasoning. The overarching question here is about the $\tau \alpha \dot{\xi} \xi \varsigma$ ("place") of the Fourth Gospel within the Christian Scriptures, a question Origen answers by giving it the most honored position - meaning not that it necessarily should be read first, but that it should be used as an interpretative key to all other Scriptures. Within the same argument, Origen also refers to the question of who the ideal reader of this Gospel would be, and gives a privileged position to a Christian reader with a personal devotion to Jesus and to his mother Mary. The third introductory question interleaved by Origen in this passage is the question of the oxorós ("aim") of the Gospel,

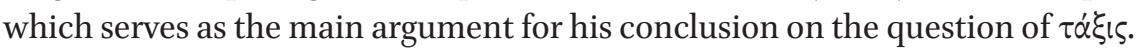
The oxo ós Origen perceives in the Gospel of John is the voûs ("meaning") he is

\footnotetext{
100 Origen, Comm. Jo., 1.4/21, 23.

101 Origen, Comm. Jo., 1.4/22-5/23 (sc, 120 bis, 66.18-68.31; ET: Heine): ... $\dot{\alpha} \lambda \dot{\alpha} \gamma \varepsilon \tau \eta \rho \varepsilon \hat{~} \tau \hat{\omega}$

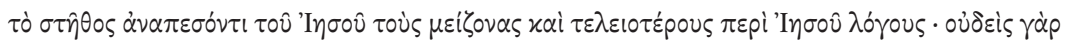

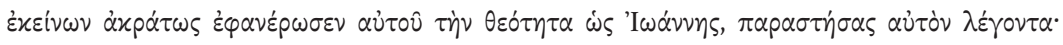

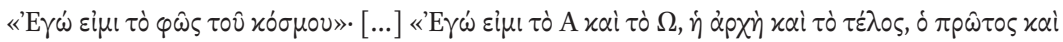

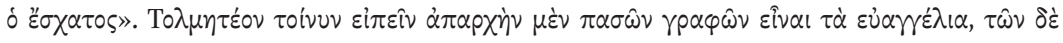

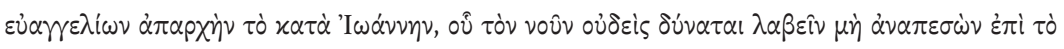

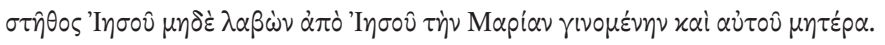


using to evaluate all biblical writings in relation to each other, which is to preach the central Christian message - or, in more specific terms, to present the $\theta \varepsilon \dot{\tau} \tau \eta \tau \alpha$ ("divinity") of Jesus. ${ }^{102}$

When addressing the question of the reason for the title ( $\dot{\varepsilon} \pi$ irpa $\left.\eta_{\eta}\right)$ ), Origen takes the opportunity to present a general definition of $\dot{\eta} \varepsilon \dot{v} \alpha \gamma \varepsilon \dot{\varepsilon} \lambda 10 v$ - a "gospel" in the third sense above - that is clearly informed by a $\gamma \lambda \omega \sigma \sigma \eta \mu \alpha \tau i x o ́ v$ ("word study") of the term:

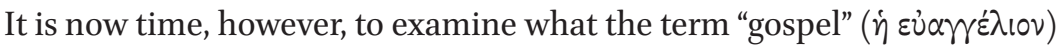

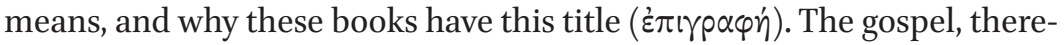
fore, is a discourse containing a report of things which, with good reason, make the hearer glad whenever he accepts what is reported, because they are beneficial. ${ }^{103}$

As is common in the Aristotelian tradition of definitions, Origen gives three alternative definitions, which are not intended to be mutually exclusive: The gospel is either (1) a statement ( $\lambda$ ó $_{0}$ s) that serves as a report of things $(\pi p \alpha \dot{\gamma} \mu \alpha \tau \alpha)$ that bring joy to the hearer, (2) a statement containing good things, or (3) a statement reporting the arrival of a good thing that the hearers have been awaiting. ${ }^{104}$ To demonstrate that the four Gospels fit these definitions of "gospel," he points out that they report (1) Christ's presence among humans, (2) the Father's presence within Christ, and (3) Christ's arrival to the Israelites who were awaiting him. From there, he returns to the point that, by extension, any written or non-written communication that teaches the central Christian message can be called "gospel," giving four specific examples: (1) Paul's preaching; (2) the result of Christian interpretation of the Hebrew Bible, using the canonical Gospels as an interpretative key; ${ }^{105}$ (3) the proclamation that at the

102 Several of these points are previously made by Heine, "Introductions," pp. 8-10. The importance of Origen's hermeneutical priority of the gospel, and his important distinc-

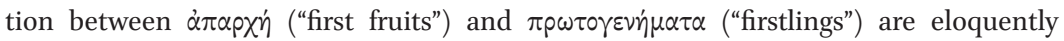
expressed by Watson, Gospel Writing, pp. 533-537. A similar point is made by McGuckin, "Origen as Literary Critic," p. 129.

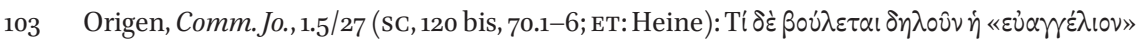

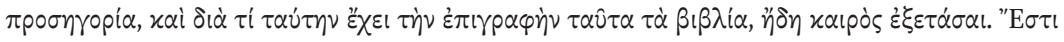

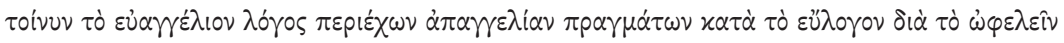

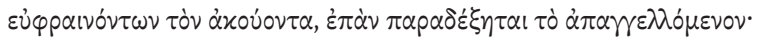

104 Heine, "Introductions," pp. 11-12; Watson, Gospel Writing, pp. 537-538.

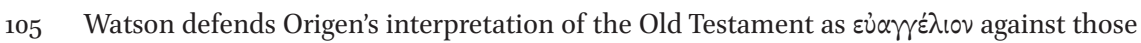
who would deem it "premodern" or "supersessionst" by characterizing it as "canonical," noting that the decision to treat certain texts as canonical belongs to the reception of the 
end of time, according to Rev 14:6, will be made known to every nation by an angel; and even (4) the good deeds of his Christian contemporaries.Thus, Ori-

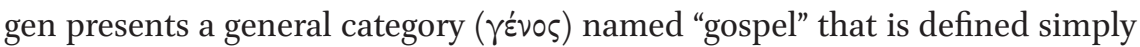
by its ability to bring joy to the hearer, and a more specific sub-category (घîंos), also named "gospel" that is defined by an educational intention to teach the central Christian message or, more specifically, to present Jesus as divine. ${ }^{106}$

Thus, Origen's inclusion, in this sub-category, of written narratives, oral preaching, literary interpretation, and even social action, is entirely compatible with Carolyn Miller's view of genre as social action. ${ }^{107}$ In terms of the concept of genre specified above, Origen's remarks define a genre characterized by an intention to teach the central Christian message, in which he thinks the four Gospels participate.

\section{Expectations of True History in the Gospels}

"Gospel" is not the only characterization Origen makes in regard to the Gospels. In the introduction to book 20 of his Commentary, he revisits the question

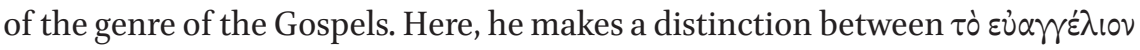
- the gospel in second sense above - and the text that he is examining which he calls $\dot{\pi} \pi \mu \nu \eta \mu \alpha \tau i x \dot{\alpha} \gamma p \alpha \dot{\mu} \mu \alpha \tau \alpha$ ("writings serving as memoirs"):

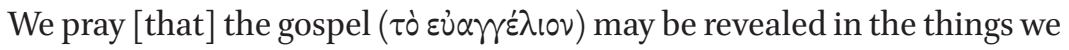
examine, and that we may neglect nothing that needs to be examined and to be believed in the writings that serve as memoirs (i $\pi 0 \mu \nu \eta \mu \alpha \tau i x \dot{\alpha}$ $\gamma p \alpha \dot{\mu} \mu \alpha \tau \alpha)$, and that we may neither claim too much, as one ought not, nor misconstrue the mind (vov̂s) of Jesus our Savior. May God, therefore, send the Word himself to us, revealing himself, that we may become beholders of his depth, if the Father grants. ${ }^{108}$

book, and does not disallow other readings in other groups (Watson, Gospel Writing, pp. 529-537).

106 It might be noted that this definition of "gospel" is completely in line with Rudolf Bultmann's claim that the Gospels have no historiographical or biographical interest, but exist solely to teach theology. See R. Bultmann, The History of the Synoptic Tradition, Oxford, 1968, pp. 367-374; Collins, Mark, p. 19.

107 Miller, "Genre as Social Action."

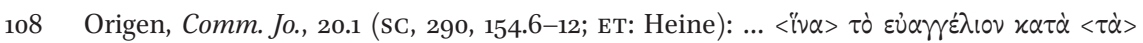

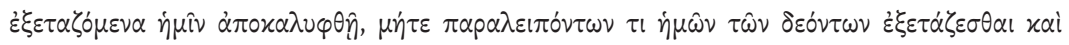

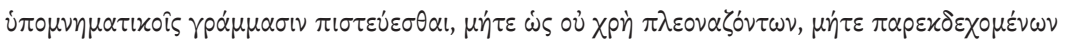


The designation $i \pi \circ \mu \nu \eta \mu \alpha \tau i x o ́ s$ reveals an interest in remembering the past, and is reminiscent of Justin Martyr's favorite designation for the Gospels: $\dot{\alpha} \pi \circ \mu \nu \eta \mu \circ v \varepsilon \dot{\mu} \mu \alpha \tau \alpha \tau \dot{\omega} \nu \dot{\alpha} \pi \circ \sigma \tau \dot{\lambda} \lambda \omega \nu$ ("memoirs of the apostles"). ${ }^{109}$ This designation has been taken as a way of accentuating the historical trustworthiness of the Gospels, ${ }^{110}$ and a similar intention may be present here. Since the context is in the middle of a dialogue between Jesus and Christ-believing Jews, ${ }^{111}$ it is not clear whether it is Jesus's teachings or the historical events that are to be remembered.

In book 10 of the Commentary, Origen goes into the chronology of the Fourth Gospel, which he compares with the Synoptic accounts. Origen notes that the remark in John 2:12 that Jesus after the wedding at Cana spent a few days in Capharnaum leaves no room for the Synoptic account of a forty-day period of temptation before the cleansing of the temple. He also notes that the fourth evangelist depicts the beginning of Jesus's public ministry to be concurrent with John the Baptist's active period, while the Synoptics claim that his ministry started after John was imprisoned. ${ }^{112}$ To explain how he views this situation, Origen tells a parable: Four men located in different cities simultaneously experience four separate spiritual experiences of God, and all four proceed to describe their experiences in writing. ${ }^{113}$ The four resulting narratives might well be quite similar and contain several common details, but it would not be straightforward to harmonize them into one believable depiction of a single past event, since what is described has, to a large extent, transpired within the authors' minds. ${ }^{114} \mathrm{He}$ also describes an interpretative framework that might be used to interpret these narratives:

To one, then, who thinks that the writing ( $\left.ү \rho \alpha \varphi \eta^{\prime}\right)$ of these men is history

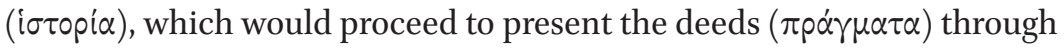

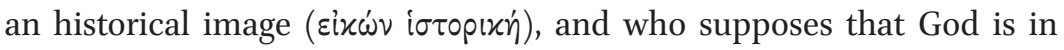
space with its limitation, not being able to produce several appearances of himself at the same time to several people in several places, and to say

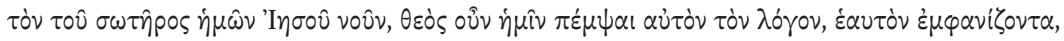

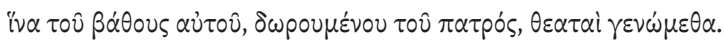

109 Justin Martyr, 1 Apol., 66.3, 67.3-4; Dial., 99-107 (13 times).

110 S. Byrskog, Story as history - History as Story: The Gospel Tradition in the Context of Ancient Oral History (WUNT, 123), Tübingen, 2000, pp. 2, 276.

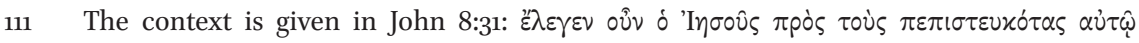
'Iovóious ...

112 Origen, Comm. Jo., 10.1/3-3/14.

113 Origen, Comm.Jo., 10.4/15-5/18.

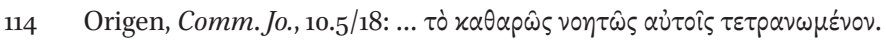


several things at the same time, it will seem impossible that the four men,

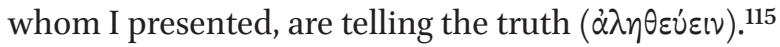

The framework consists of two premises: (1) to view these writings as a kind

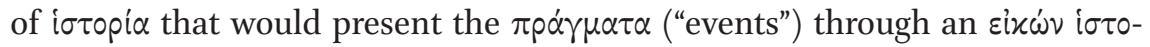
pixí;116 and (2) to assume that the narrative character "God" is confined to one geographical location at a time. The false conclusion that the four authors are lying would be reached simply from the second premise, and it is clear from the context that Origen's negative stance towards this interpretative framework does not really extend to the view that the writings of the evangelists is

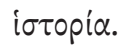

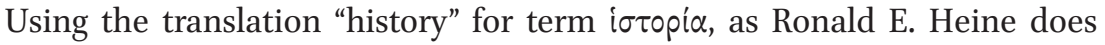
above, is problematic, however. In several attestations of the term, i $\sigma \tau$ iopi $\alpha$ does not denote a description of past events but an investigation or inquiry of any subject and, by extension, the written account in which such an investigation

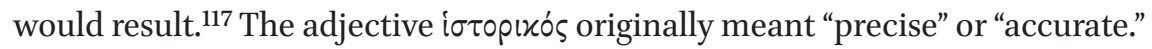
Even when a more specialized sense originated with Aristotle, where $\pi \rho \alpha \gamma \mu \alpha \tau \alpha$

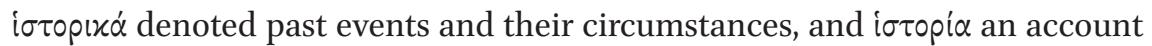
of such, the more general sense continued to be in use. ${ }^{118}$ It is clear from the context of Origen's parable that these $\pi \rho \alpha \gamma \mu \alpha \tau \alpha$ are past events: either the ex-

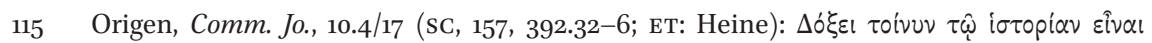

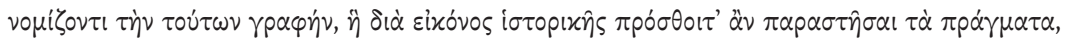

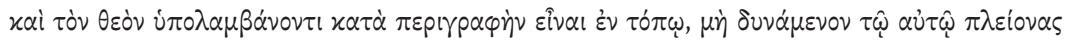

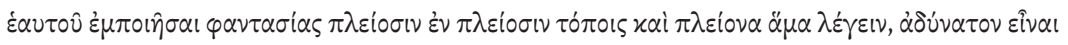

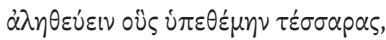

116 The translation of this expression is discussed below. In Heine's translation cited above, it is translated "historical image."

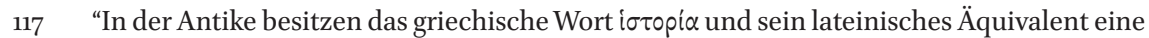
doppelte Bedeutung. Sie besagen, wie schon angedeutet, Erforschung und Erzählung” (B. Studer, "Der Begriff der Geschichte im Schrifttum des Origenes von Alexandrien," in: Origeniana octava: Origen and the Alexandrian tradition, ed. L. Perrone (BETL, 164), Leuven, 2003, pp. 757-777, here 759). Herodotus uses the term in the sense of inquiry in Hist. 2.118 and of the information so acquired in Hist., 2.99. A third-century BCE inscription (ogIS 13.12) uses it in parallel to $\mu \alpha p \tau$ pía. See D. Iordanoglou and M. Persson, "Tidigare än, men ändå samtida. Om det förflutna i antik grekisk historieskrivning [Earlier than, but still contemporary. On the past in ancient Greek historiography]," Lychnos, (2012), pp. 93-134, here 95-99, 111-112.

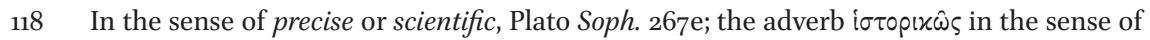

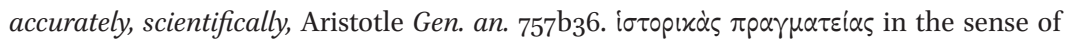
past events, Dionysius of Halicarnassus Ant. rom. 1.1. Iordanoglou and Persson, “Tidigare," pp. 97, 99 . 
periences of his four hypothetical authors or the events in the life of the his-

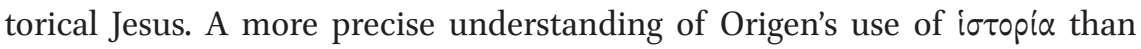
Heine's "history" would be an "account" of these past events. ${ }^{119}$ Since past events are already historical, it would be redundant to present them through a

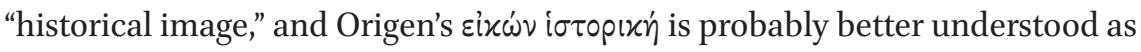
denoting an accurate depiction, especially in view of Origen's evaluative question whether the authors are telling the truth $(\dot{\alpha} \lambda \eta \theta \varepsilon \dot{\varepsilon} \varepsilon v)$. Hence, Origen is presenting another genre in which he thinks the Gospels participate: they are accounts of past events, intended to depict these events accurately.

What can we expect from an ancient writer's accurate depiction of past events? Any comparison between ancient historiography ${ }^{120}$ with its modern counterpart is bound to reveal large differences. The ancient writers do not meticulously specify their sources. They frequently ascribe thoughts and feelings to historical figures, apparently without reflecting on the accuracy of these depictions. They include material that a modern historian would set aside as legendary. Inserted speeches tend to be suspiciously similar in style to the voice of the narrator. To many modern readers, ancient historiography sometimes seems closer to modern historical fiction than to modern historiography. ${ }^{121}$ On the other hand, to simply dismiss all instances of ancient historiography as fiction, albeit containing some historical information, would not be fair. Greek historians such as Herodotus ( $c a .484-425$ BCE), Thucydides ( $c a .460-400$ BCE), and Polybius ( $c a .200-118$ BCE) worked from oral and writ-

119 The more neutral "account" is also consistent with Origen's usage of i $\sigma \tau \circ$ pi $\alpha$ in other contexts, where he states that i $\sigma \tau$ opi $\alpha$ is written, read, presented, heard, learnt, transmitted, quoted, and recognized - all verbs applicable to written accounts in general. Basil Studer even suggests that the Latin word textus sometimes might be an accurate substitution: "Man kann sich selbst fragen, ob das lateinische Wort textus nicht manchmal in diesem bildlichen Sinn zu verstehen ist” (Studer, “Der Begriff der Geschichte," pp. 761-762).

120 The word "historiography" is here used to denote a narrative written account that is the result of the work of an ancient or modern historian. The term "ancient history" would refer to events that took place in antiquity, "ancient historiography" to ancient accounts of history. For an overview of the development and variation of the genre of historiography in Greco-Roman antiquity, see Marincola, "Greco-Roman Historiography," pp. 283290, 309-320.

121 D. Boedeker, "Herodotus's Genre(s)," in: Matrices of Genre: Authors, Canons, and Society, ed. M. Depew and D. Obbink (Center for Hellenic Studies colloquia, 4), Cambridge, 2000, pp. 97-114, here 99; J. Marincola, Greek Historians (Greece \& Rome, 31), Oxford, 2001, pp. 31-39; L. Pitcher, Writing Ancient History: An Introduction to Classical Historiography, London, 2009, pp. 5-14; Iordanoglou and Persson, “Tidigare," pp. 102, 104. 
ten sources as well as from personal observation, and were well aware of the difference between perception and hearsay. ${ }^{122}$

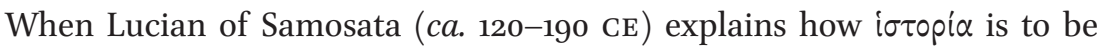
written, he incessantly repeats that the historian has to search for the truth. While the poet is free to invent winged horses and the encomiast may lie to please his subject, the historian is bound by the events that really happened. A historian should primarily search for facts, investigating the same matters over and over again, if possible on location. The reliability of every informant must be evaluated, and only the accounts of the most impartial ones should be included. The findings from the inquiry should be organized skillfully, however, and expressed as vividly as possible, adding color and ornament. Ideally, the hearers of the account should be able to imagine that they see the events happen. Inserted speeches should primarily be "suitable to the speaker and the situation," but can certainly be embellished by the author's rhetorical and stylistic ingenuity. ${ }^{123}$ While today's sharp boundary between fiction and non-fiction is inapplicable to the kind of literature he describes, Lucian cannot be said to ignore questions about truth, fact or source evaluation. ${ }^{124}$

Clearly, perceptions of truthfulness varied between different ancient historians. To gain a sense of to what extent, T.P. Wiseman has reviewed instances where ancient authors accuse ancient historians of telling lies. In his findings, the most common cause for complaints is partiality, but the narration of obvious impossibilities and neglect of evaluating the truthfulness of informants' reports are also represented in the material. While one author - Polybius of Megalopolis ( $c a$. 199-120 BCE) - accuses his contemporaries of too much elab-

122 Boedeker, "Herodotus's Genre(s)," pp. 98-102, 108-114; Iordanoglou and Persson, "Tidigare," p. 98; C. K. Rothschild, Luke-Acts and the Rhetoric of History: An Investigation of Early Christian Historiography (WUNT, II 175), Tübingen, 2004, pp. 222-225; Byrskog, Story as History, pp. 53-65. On Herodotus, specifically, Deborah Boedeker concludes: "Herodotus, on the other hand, makes much of assessing the quality of his sources and allowing his readers to do the same; he teaches his audience to judge accounts critically, on the basis not only of their likelihood but also of their source, which can be biased because of the speaker's self-interest or the predispositions of a narrative genre. His new genre is dedicated both to commemorating human things that were said and done, and to commemorating and demonstrating the many processes by which those things are discovered and evaluated" (Boedeker, "Herodotus's Genre(s)," p. 114).

123 Lucian of Samosata, How to Write History, translated by D. A. Russell in: D. A. Russell and M. Winterbottom, Ancient Literary Criticism: The Principal Texts in New Translations, London, 1972, pp. 536-547.

124 A. D. Walker, "Enargeia and the Spectator in Greek Historiography," Transactions of the American Philological Association, 123 (1993), pp. 353-377, here 354; Iordanoglou and Persson, “Tidigare," p. 102. 
oration of the facts, a more common complaint is the absence of elaboration. Notably, the process where the historian selects what is worthy of retelling and arranges this material into a coherent narrative $\left(\dot{\alpha} \varphi \eta^{\prime} \gamma \eta \sigma / \zeta\right)$ is also considered a

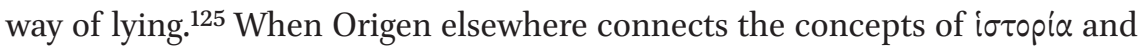
$\alpha \lambda \eta^{\prime} \theta \varepsilon ı \alpha$ ("truth"), it is frequently to stress the dependability of biblical accounts of past events. One of his arguments for this reliability is their connection to either the divine Logos or the Holy Spirit, an argument that admittedly is more theological than historiographical, but still not without perceived validity in the ancient world. ${ }^{26}$

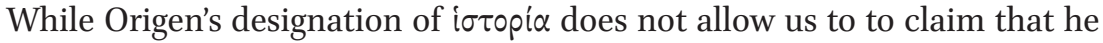
viewed the Gospels as historiography in accordance with modern standards, his specification that the $\pi p \alpha \gamma \gamma \mu \alpha \tau \alpha$ ("events") in question are to be expressed

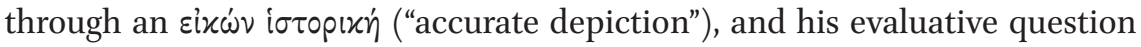
whether their authors are telling the truth $(\dot{\alpha} \lambda \eta \theta \varepsilon \dot{\varepsilon} \varepsilon v)$, results in a genre definition comparable, at least, to the Histories of Herodotus. ${ }^{127}$ Origen viewed the Gospels as accounts of past events, intended to depict these events accurately.

\section{Perceived Genre Participation of the Gospels}

In the conclusion to his parable about four hypothetical authors who report their own spiritual experiences, Origen admits that the Gospels contain some historical information that is untrue. He explains this by locating some of the aspects of the past events that are narrated, not to the outer historical reality, but within the minds of the Gospel authors. Their intention, he states, was to transmit, in written form, what they had seen in their mind. They made use of many things said and done by Jesus, but sometimes they interwove, in their narratives, something made clear to them in a purely intellectual manner. ${ }^{128}$

125 Wiseman's conclusion is that we are blind to the notion of truth in ancient historiography, since it is too different from our own. In my view, he thereby neglects the diversity of his own material; it cannot be brought to conform to such a single notion of truth. See T. P. Wiseman, "Lying Historians: Seven Types of Mendacity," in: Greek and Roman Historiography, ed. J. Marincola (Oxford Readings in Classical Studies), Oxford, 2011, pp. 314-336; Byrskog, Story as History, pp. 200-202.

126 Studer, “Der Begriff der Geschichte," pp. 765-768.

127 Studer, "Der Begriff der Geschichte," p. 767: "Mit dieser Bemerkung ist bereits ausgespro-

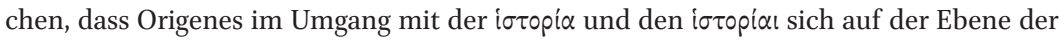
damaligen Geschichtsschreibung bewegt."

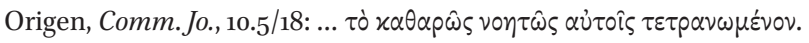


This is permissible, he argues, in view of their primary goal with the narrative: to accurately teach the central Christian message: ${ }^{129}$

For their intention was to speak the truth spiritually and materially at the same time where that was possible but, where it was not possible in both ways, to prefer the spiritual to the material. The spiritual truth is often preserved in the material falsehood, so to speak. ${ }^{130}$

It is beyond doubt that Origen valued the historical accuracy of the Gospel narratives, and that his theology depended on the truthfulness of their descriptions of past events. ${ }^{131}$ But such a statement does not exhaustively describe Origen's views of the nature of the Gospels. Even more important than historical accuracy is theological precision, which leads him to this complex model in which the Gospels are Christian teachings first, historical truth second. As these reflections demonstrate, this is not a simple reading strategy, intended to let him use the Gospels as proof in both historical and dogmatic matters, but a result of conscious reflection on the characteristics of the texts and the perceived intentions of their authors. As Francis Watson has pointed out, it is easy to see that Origen's hermeneutical reflections could not have taken place without the influence of an emerging Christian canon. Had Origen recognized only one of the Gospels, he would have had no need to reconcile the differences between them. It is precisely the juxtaposition of four canonical narratives that prompts him to prefer a theological interpretation, ${ }^{132}$ and forces him to adopt a complex view of the nature of the Gospels. As stressed by Karen Jo Torjesen, Origen's view of the divine Logos as the ultimate originator of spiritual truth in the Christian Scriptures is another important factor behind his

129 Origen, Comm. Jo., 10.5/18-19. As Watson points out, this might be a later development than the simple assumption, in $6.18 / 171-2$, that since John in Matthew is unworthy to carry Jesus' sandals rather than to untie them as in Mark, John must have said both things at different occasions. See Watson, Gospel Writing, pp. 547-8.

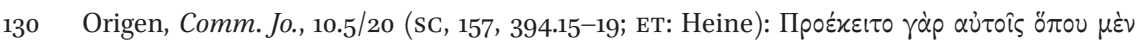

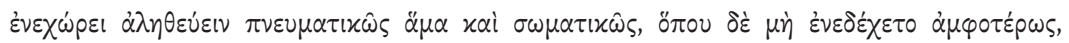

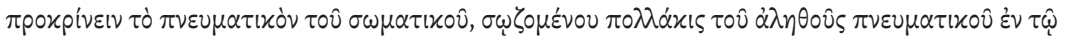

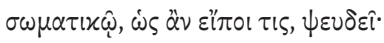

131 Studer, "Der Begriff der Geschichte," p. 774: "Dennoch lässt er darin keinen Zweifel darüber, dass nach seiner Auffassung der kirchliche Glaube in einem geschichtlichen Vorgang weitergegeben wird und auf diese geschichtliche Weise die Basis allen theologischen Denkens bildet."

132 Watson, Gospel Writing, pp. 548-552. 
view of the Gospels. ${ }^{133}$ Without this constraint, Origen's view of the Gospels could have been much simpler.

We may conclude, then, that the use of introductory questions from Greek philology to analyze Origen's commentaries to biblical writings has led to a developed understanding of Origen's views on the nature of the Gospels in the New Testament. The six questions presented by Ammonius are recognizable in Origen's writings, and reveal certain aspects of his chain of reasoning. In this analysis, Origen's reflections on the nature of the Gospels expose a complex model in Origen's thinking, in which the Gospels are considered to primarily teach the central Christian message, and secondarily be dependable historical accounts. In terms of modern genre theory, Origen's view on the nature of the Gospels can be expressed as their simultaneous participation in two genres: Primarily, they are $\varepsilon \dot{u} \alpha \gamma \varepsilon \dot{\lambda} \lambda 10 \mathrm{v}$ ("gospel"), defined by an authorial intention to teach the central Christian message or, more specifically, to present the divin-

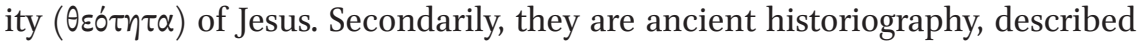
by Origen as accounts of past events, intended to depict these events accurately.

133 Torjesen, Hermeneutical Procedure, pp. 129-130, 138-147. 